\title{
Population and Economic Cycles in the Main Spanish Urban Areas: The Migratory Component ${ }^{*}$
}

\author{
Fernando Gil-Alonso, Jenniffer Thiers-Quintana
}

\begin{abstract}
The paper aims to analyse how the different economic phases that Spain has experienced in the first two decades of the $21^{\text {st }}$ century (expansion, recession, and recovery) have influenced population stocks and migratory flows in the five largest metropolitan areas defined as Functional Urban Areas (FUAs) in Spain: Barcelona, Bilbao, Madrid, Seville and Valencia. Using Padrón Continuo (municipal registers) and Estadística de Variaciones Residenciales (residential change statistics) as data sources, both native and immigrant - i.e. born abroad - stocks, and internal and international migration flows are analysed. We study differences between (a) diverse groups of foreigners (by continental origin), also comparing them to natives; and (b) different types of residential mobility by migrants' previous place of residence: "intrametropolitan" movements (between urban cores and peripheries), migration flows between the five urban areas and the rest of Spain, and international migration.

Results show that intrametropolitan migration flows between the five urban cores and their peripheries were characterised by suburbanisation during the expansion phase. These flows were particularly relevant for Spanish-born persons and, among foreign-born migrants, for people born in the Americas (mainly Latin Americans). These flows to the suburban periphery decreased during the economic crisis, and in 2013 and 2014 net intrametropolitan migration of most foreign groups was characterised by recentralisation. Spaniards' intrametropolitan movements almost reached equilibrium during the recession years: Natives decreased their moves from cores to rings, while they were increasingly attracted to urban centres. Owing to the incipient economic recovery, suburbanisation is progressively recovering its previous strength. As for other types of residential moves, foreign-born migrants moving from abroad and the rest of Spain to the five FUAs during the economic expansion phase reversed the direction of their flows in the economic crisis years, migrating abroad or dispersing throughout Spain in search of jobs. Consequently, their stocks declined in some years. Currently, due to the incipient
\end{abstract}

This article belongs to a special issue on "Internal Migration as a Driver of Regional Population Change in Europe: Updating Ravenstein". 
economic recovery, the five FUAs are attracting internal and international foreignborn immigrants once again, so their foreign-born population stocks are increasing in both cores and peripheries. Spaniards show the opposite behaviour regarding flows to and from the five areas analysed - they tended to disperse throughout the rest of Spain during the economic expansion phase. This trend continued during the crisis years, but at a slower pace, as natives became increasingly attracted to urban cores. Furthermore, this latter trend has strengthened during the post-crisis years. Finally, considering foreign-born and Spanish populations together, large urban areas are increasingly attractive. This global tendency is to the detriment of rural areas and of non-metropolitan small and medium size towns, which lose population due to negative net migration.

Keywords: Residential mobility · Migration · Population change · Urban areas · Spain

\section{Introduction}

According to Ravenstein's (1885) influential paper The laws of migration, most migrations are economically driven. Ravenstein described "a universal shifting or displacement of the population, which produces 'currents of migration' setting in the direction of the great centres of commerce and industry which absorb the migrants" (first law; ${ }^{1}$ Ravenstein 1885: 198). Today, large urban areas continue to be main poles of attraction for immigrants.

Most $19^{\text {th }}$ century migrants settling in English cities and towns with vibrant economies made short-distance moves (first law; Ravenstein 1885: 198), although others migrated from further places (second ${ }^{2}$ and fifth laws; ${ }^{3}$ Ravenstein 1885: 199). Currently, metropolises also receive immigrants from nearby municipalities, from the rest of the region or the country, or from abroad. These inflows make cities

1 This first law continues: "In forming an estimate of this displacement we must take into account the number of natives of each county which furnishes the migrants, as also the population of the towns or districts which absorb them" (Ravenstein 1885: 198). According to Greenwood (2019: 272), this statement, and the previous reference to distance, clearly contains elements of the gravity law of migration. Similarly, Ravenstein's implicit attribution of rural-to-urban migrations to differences in economic opportunities can be interpreted as a reference to "pull" and "push" factors (Greenwood 2019: 272).

2 "The inhabitants of the country immediately surrounding a town of rapid growth, flock into it; the gaps thus left in the rural population are filled up by migrants from more remote districts, until the attractive force of one of our rapidly growing cities makes its influence felt, step by step, to the most remote corner of the kingdom" (Ravenstein 1885: 199).

3 "Migrants proceeding long distances generally go by preference to one of the great centres of commerce or industry" (Ravenstein 1885: 199). 
grow, decreasing the share of natives and increasing that of immigrants. ${ }^{4}$ At the same time, other migrants leave these large urban areas, some of them returning to their places of origin, creating counter-flows as Ravenstein hypothesized in his third $^{5}$ and fourth laws ${ }^{6}$ (Ravenstein 1885: 199). These in- and out-flows to or from the metropolitan areas fluctuate, now as in Ravenstein's times, mainly for economic reasons. This influence on residential moves, causing positive or negative net migration, is exerted either directly through the labour market, or indirectly, through the real estate market. Therefore, migrations should be very sensitive to changes in the economic cycle.

Taking this hypothesis based on Ravenstein's thoughts as a starting point, this paper's aim is twofold. First, it intends to analyse how the different economic phases that Spain has undergone in the first two decades of the $21^{\text {st }}$ century (expansion, recession, and recovery) have influenced internal and international migrations of both native and immigrant (born abroad) populations in the five largest Spanish metropolitan areas: Barcelona, Bilbao, Madrid, Seville and Valencia (Fig. 1). Second, the paper aims to study the role of migration as a driver of population change in the core cities and the peripheries of these five urban areas.

Ravenstein used census data by county of residence and county of birth along with vital statistics records and data on country of birth, to study lifetime placeto-place migration and the net balance of migration (Greenwood 2019: 272). The present paper uses stock and flow information from INE (the Spanish National Statistical Institute) to carry out the analysis. First, residential change statistics (Estadística de Variaciones Residenciales or EVR) flow data between 2005 and 2016 are used to describe migratory flows (residential changes) from, to, and within the functional urban areas. In addition, the continuous municipal population register or Padrón continuo ${ }^{7}$ provides population stocks on January 1 every year from 2005 to 2016, permitting the calculation of annual growth figures. All these data are used to analyse differences between: (a) diverse groups of foreigners, by continental origin, comparing them to natives; and (b) different types of residential mobility according to migrants' previous place of residence. Residential mobility is classified as intrametropolitan (moves between urban cores and peripheries of the five met-

4 In Ravenstein's words: "There are towns which, either on account of their size or rapid growth, absorb so considerable a number of migrants, that the resources in men of the country immediately surrounding them are not able to supply their wants. In towns like these the native county element, owing to the inflow of strangers, sinks below what it is in the surrounding country" (Ravenstein 1885: 205).

5 "The process of dispersion is the inverse of that of the absorption, and exhibits similar features" (Ravenstein 1885: 199).

6 "Each main current of migration produces a compensating counter-current" (Ravenstein 1885: 199).

7 All the residents of a municipality, including foreigners, have the right and the duty to register with the local Padrón, independent of their legal situation. Most illegal immigrants do register as this gives them access to public health and education systems. Regarding EVR, this database collects changes in the Padrón, that is to say, residential moves between Spanish municipalities. As for flows between Spanish municipalities and abroad, they are also included, though the quality of these data is lower. 
Fig. 1: Boundaries of the five analysed Functional Urban Areas

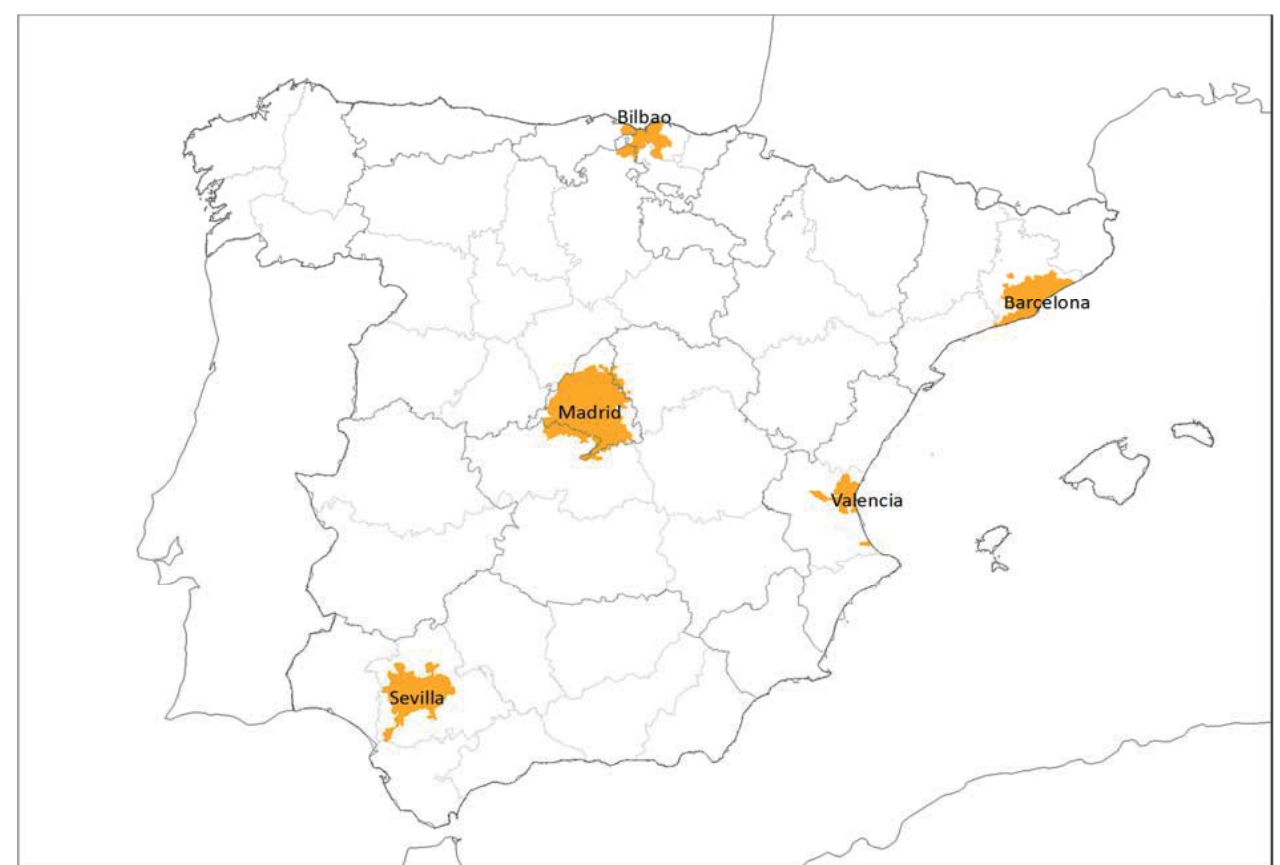

Source: Indicadores Urbanos, Spanish National Statistics Institute (INE), based on Eurostat's FUA definition

ropolitan areas), migration flows between the five urban areas and the rest of Spain, and international migration. The latter analysis mirrors Ravenstein's 1885 paper, distinguishing the "native county element" from the "border element" (residents of a county who were born in neighbouring counties), to differentiate between shortdistance and long-distance migrants (Greenwood 2019).

The five metropolitan areas analysed are delimited following the Functional Urban Area (FUAs) criteria established by Eurostat's Urban Audit European database (Fig. 1). ${ }^{8}$ Each FUA consists of a city or core and its commuting zone or periphery. ${ }^{9}$

8 See definitions of spatial units used by Urban Audit at: https://ec.europa.eu/eurostat/web/cities/spatial-units

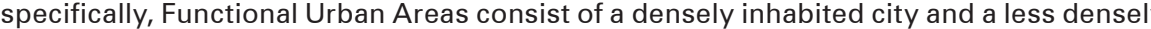
populated commuting zone whose labour market is highly integrated with the city. In other words, a sum of local territorial units (municipalities in the Spanish case) in which a significant part of the resident employed population works in the city that gives name to the FUA. Thus, a municipality belongs to the FUA of a certain city if at least 15 percent of its working population commutes to that city for work. However, municipalities under 2,000 inhabitants may also be included according to the following criteria. Those with 1,000-2,000 inhabitants are incorporated if 25 percent of those employed commute to the city that gives name to the FUA; for those with $500-1,000$ inhabitants, the threshold is 35 percent; for those with $100-500$ it is 45 percent; and, finally, for municipalities under 100 inhabitants, the threshold is 50 percent. The percentage of commuters is the main criterion, but there are also others, such as contiguity (Eurostat 2017). 
According to the definition of Functional Urban Area used in the article, the Madrid FUA comprises 137 municipalities, while that of Barcelona is made up of 129. In Madrid, there are 6.5 million people living in the whole FUA, 3.2 million of which reside in the core city and the rest in the periphery. The Barcelona FUA has 4.9 million inhabitants, 1.6 million of which reside in the core and the rest in ring municipalities. The other three areas analysed are smaller and have fewer residents both in the whole FUA and in the cores: Valencia (1.6 and 0.79 million residents, respectively), Seville (1.4 and 0.69 million), and Bilbao (1.021 and 0.345 million). In total, 15.5 million people, approximately a third of the Spanish population, live in these five FUAs. Madrid, Barcelona and Valencia are the most dynamic FUAs, and most foreign-born immigrants settled there in the economic boom years. Seville and Bilbao received fewer born-abroad immigrants during that period. However, while Bilbao is situated at the centre of an industrial area which absorbed the impact of the economic crisis somewhat better, Seville has a less dynamic economy and has found it harder to recover from the economic recession.

This paper also offers further relevant results by differentiating cores and peripheries. We show how migratory flows contribute to population concentration (urbanisation) and deconcentration (suburbanisation, counter-urbanisation) in metropolitan areas. We compare intensity and timing differences between native, foreign-born and total population growth, in the five areas analysed. Finally, we show differences in internal and international migration patterns between native-born and foreign-born migrant groups, and their responses to economic cycles in the first two decades of the $21^{\text {st }}$ century.

These analyses build on recent research undertaken by the authors and their research group. Previous results show an increasing population growth and age structure divergence within Spanish urban regions since the end of the $20^{\text {th }}$ century. This has caused population growth and rejuvenation in some areas and demographic decline and ageing in others (Thiers-Quintana/Gil-Alonso 2019; Gil-Alonso et al. 2018).

The paper is organised as follows. After the Introduction, the paper includes a Background section, covering the economic context, the theoretical framework, and a literature review. Then, the main section, Results, describes research outcomes for flows and stocks. Finally, the Conclusions highlight the most relevant findings, situating these contributions within the broader contexts of our current research project - the impact of these residential changes on metropolitan spatial diversification - and links our $21^{\text {st }}$ century analysis to Ravenstein's ideas from the $19^{\text {th }}$ century.

\section{Background}

During the strong economic growth period that Spain underwent from the end of the 1990s to 2008, millions of jobs were created, with annual employment growth rates of around 4 percent until the third quarter of 2007 (Fig. 2). These new jobs, mainly in the construction and services sectors, attracted millions of foreign immigrants, particularly in the early $21^{\text {st }}$ century. Therefore, the number of foreign 
Fig. 2: Annual employment growth rates (\%), Spain, 2005-2016, quarterly data

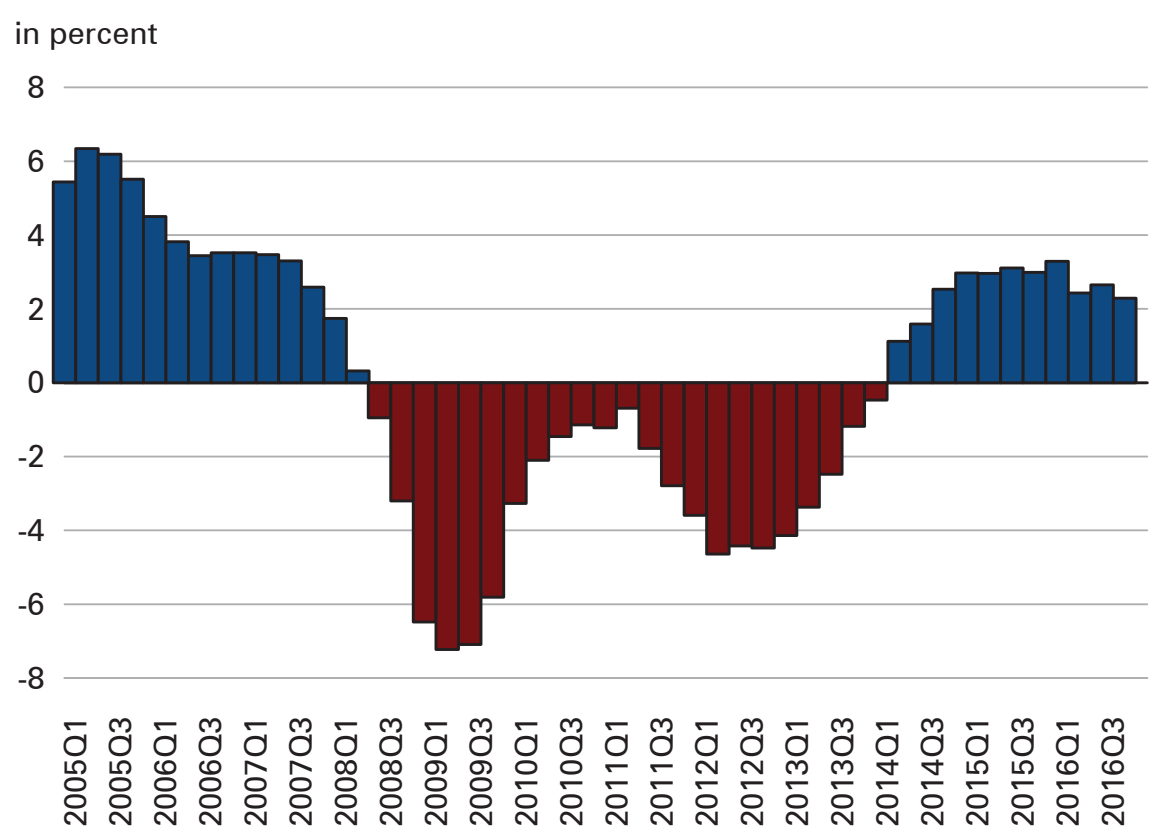

Source: Spanish Labour Force Survey (EPA), Spanish National Statistics Institute (INE)

employed people, totalling less than half a million in the year 2000, was more than 2 million in 2005 and reached a maximum of 3 million in 2008, according to Spanish Labour Force Survey data (Fig. 3). The annual inflow of foreigners from abroad increased from about 300,000 in 2000 to more than 900,000 in 2007 (Fig. 4) and the number of foreign-born persons residing in Spain peaked at more than 6.5 million (Fig. 5), that is to say, around 14 percent of Spain's population, in 2012.

The Great Recession, the global economic crisis that began in 2007, originally affecting only the financial sector, reached Spain in 2008, where the "real estate bubble" burst. Its consequences - many housing developments remained unfinished, thousands of workers were laid off - were later felt by other economic sectors, such as industry. Therefore, annual employment growth rates quickly became negative (Fig. 2), the number of foreigners with a job decreased by half a million in just two years (Fig. 3), and the number of unemployed foreigners increased from about 400,000 in 2007 to 1.2 million in late 2010 .

After the Spanish economy slowly recovered from the 2008-2009 global financial crisis in 2010 and Quarter 1 of 2011, a monetary debt crisis, lasting from 2011 to 2013 , began. It particularly affected Southern European countries and led to the implementation of EU adjustment policies, which had an important impact on consumption, the service sector, and public employment (Fig. 2). Consequently, the number of foreigners in employment in Spain fell by nearly 900,000 between Quarter 2 in 2011 and Quarter 1 in 2014 (Fig. 3). Hence, since 2008, and because of the fall- 
Fig. 3: Employed foreigners in the Spanish labour market (in millions), 20022016, quarterly data

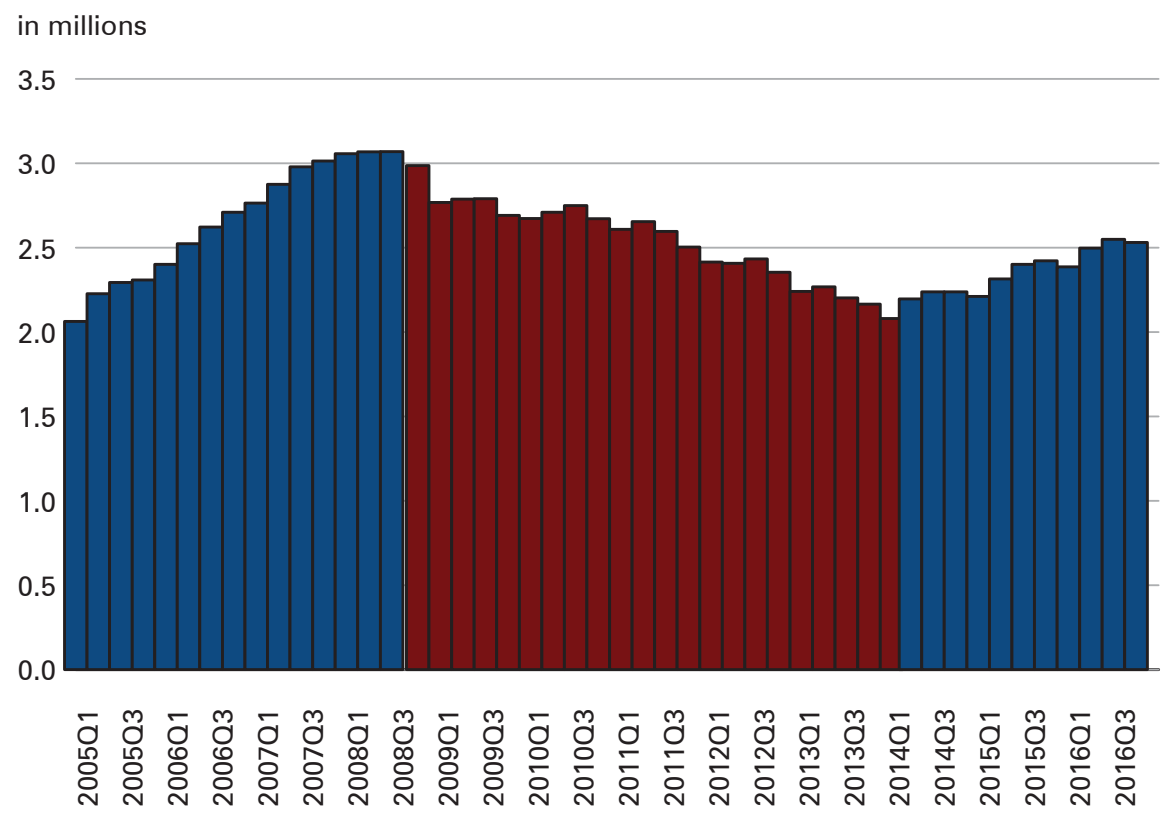

Source: Spanish Labour Force Survey (EPA), Spanish National Statistics Institute (INE)

ing employment demand, foreign immigrant entries have been rapidly decreasing (Fig. 4) and exits increasing, either to return to their countries of origin or to move to a third one. Even if foreigners' emigration flows are underreported by Spanish sources (Gil-Alonso 2010), they show that international net migration became negative (Fig. 4) and foreign-born population stocks decreased (Fig. 5) in some years.

However, this reduction of foreign-born population stocks has not been as strong as could be expected given the intensity of the economic crisis. Most foreigners remained in Spain. In fact, the population of those born in Africa and especially Asia increased. Europeans (Bayona/Gil-Alonso 2016) and Latin Americans (Bayona et al. 2017; Quintero-Lesmes 2016; Prieto/López-Gay 2015) are the only groups of immigrants that left in large numbers because of the recession (Fig. 6). Moreover, as a result of another change in the economic cycle since 2014 (Fig. 2), international net migration has become positive once more (Fig. 4) and the foreign-born population is currently increasing again - particularly that of Latin American origin (ThiersQuintana/Gil-Alonso 2019).

Why were there no strong return movements, given the intensity of economic recession? This common feature of European and United States flows (Castles 2009, 2011; Castles/Miller 2010) could have several causes. These include the fear of not being able to return if they leave due to increasing migratory controls, and poor labour prospects in their countries of origin. Return flows could be driven more strongly by economic, political, and social changes in the countries of origin, and 
Fig. 4: Foreign immigrant annual entries, exits, and net migration growth, Spain, 2005-2016

in units

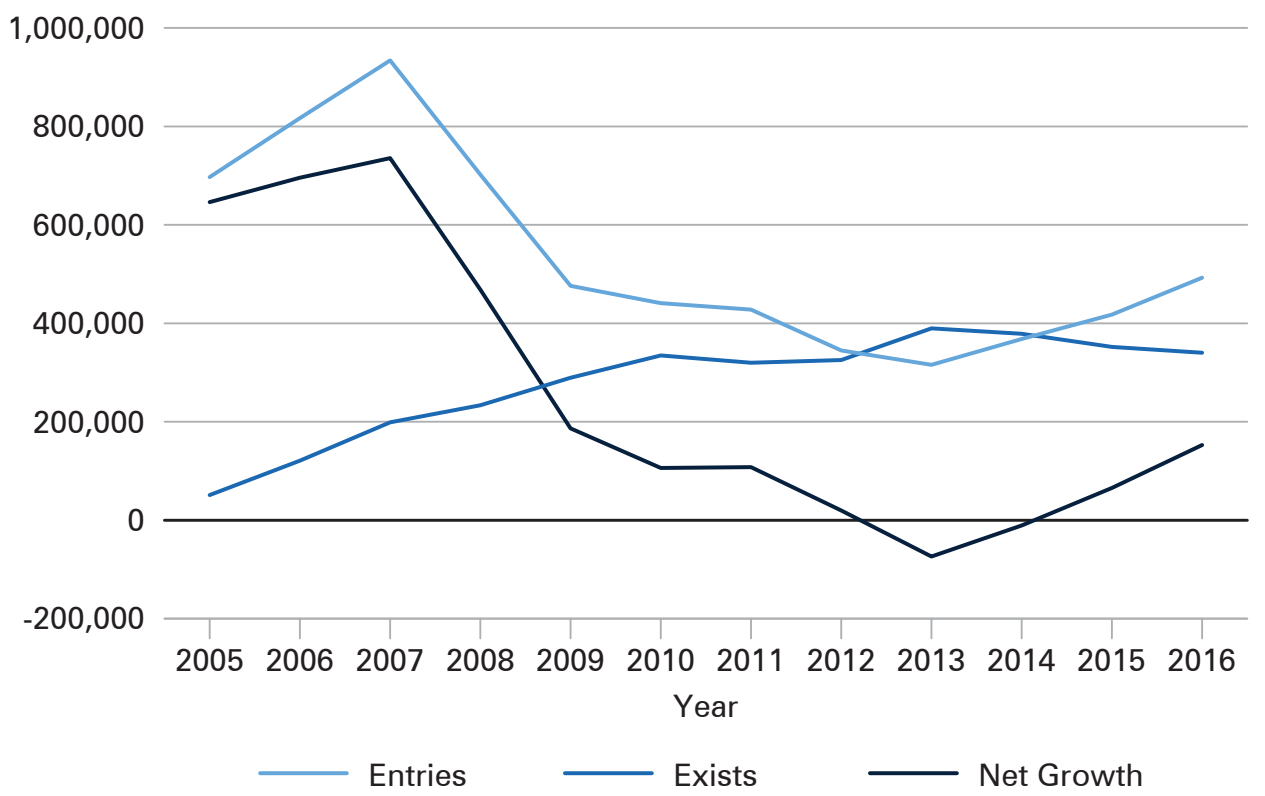

Source: Residential Variation Statistics (EVR), Spanish National Statistics Institute (INE)

the capacity to circulate between countries, than by the economic situation in the receiving society (Papademetriou/Terrazas 2009). ${ }^{10}$

Other authors (Fielding 2010; Awad 2009; Fix et al. 2009; Castles 2011) have formulated other hypotheses focusing on labour market characteristics in host countries to explain why, in the current phase of post-Fordist capitalism, migrants do not return in large numbers. This research suggests a "new immigration model" (King et al. 1997) that requires migrants to fill low wage and unstable jobs. Most migrant workers are "gap fillers". That is, they do jobs locals cannot or will no longer do

10 Therefore, many immigrants prefer to resist the effects of the economic crisis in the receiving country, even if it implies facing strong material deprivation, in the hope that a future economic recovery will generate new jobs. Only when the economic situation has substantially improved in their countries of origin, or when migrants are guaranteed future re-emigration, they return in significant numbers (for example, Poles who migrated to Britain and Ireland). If this is not the case, returning is a less popular option (Ratha et al. 2009). As examples in Spain or the Czech Republic show, incentives for unemployed immigrants to return have generally not achieved this objective. Those who do return are typically immigrants whom host countries would have liked to retain. In other words, they are workers with enough training, skills, prospects, and secure legal status to allow them to once again return to the receiving country when the labour market improves again. 
Fig. 5: Foreign and foreign-born population stocks (in millions) in Spain on January 1st, 1998-2016

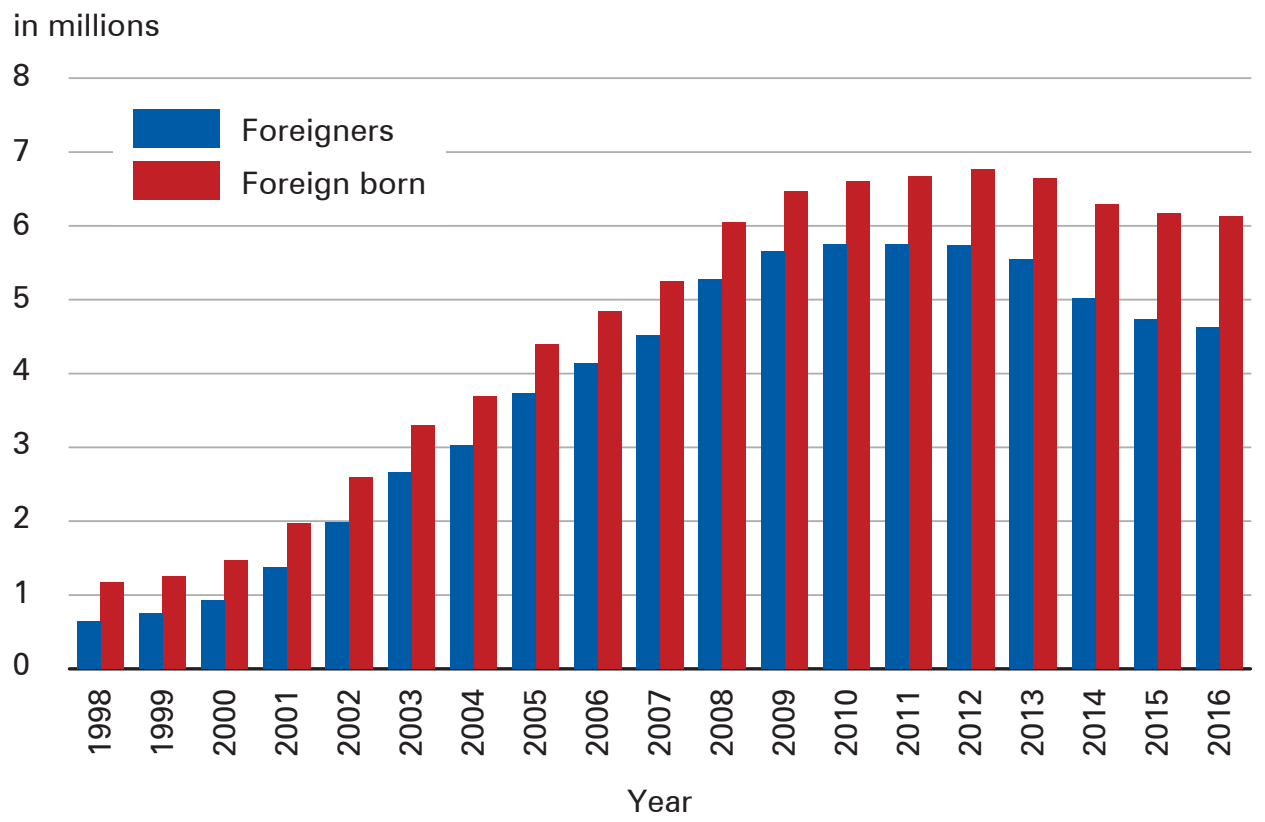

Source: Padrón continuo (continuous municipal population register), Spanish National Statistics Institute (INE)

(Abella/Ducanes 2009). They are overrepresented in less-regulated sectors such as construction, intensive agriculture, low value-added manufacturing, restaurants, tourism and leisure, domestic service, and the care of elderly and dependant people. However, working in precarious jobs may have allowed foreign immigrants to adjust faster and better than native workers to the novel and changing labour market conditions introduced by the economic crisis, as they may be more willing to take more precarious jobs and to change residence for work-related reasons (Fielding 2010). ${ }^{11}$

11 Fielding (2010) uses this approach to explain why East Asian and Southern European countries (highly dual labour markets, with low and high productivity sectors) received so many foreign immigrants until 2008, and why few migrants returned. According to Fielding, the growing differences in the type of jobs of local and immigrant workers would play in favour of the latter during economic recession, when jobs become scarce and precarious. Fielding and other authors (Castles 2011; Ghosh 2009; Dobson et al. 2009) claim that this argument contradicts the widely accepted buffer theory. The buffer theory proposes that foreign migrants provide labour to host countries during economic expansion and reduce the impact of labour market crisis, by being the first workers fired, forcing them to return to their origin counties. Fielding (2010) claims that the buffer theory, in which migrant workers feel the strongest impact of the economic crisis, could have been true in the former Fordist economy, but seems to be less valid in the current neo-liberal capitalist context. 
Fig. 6: Foreign-born population stocks by place of birth (in millions). Spain, 1998, 2003, 2008, 2013, and 2016

in millions

3.0
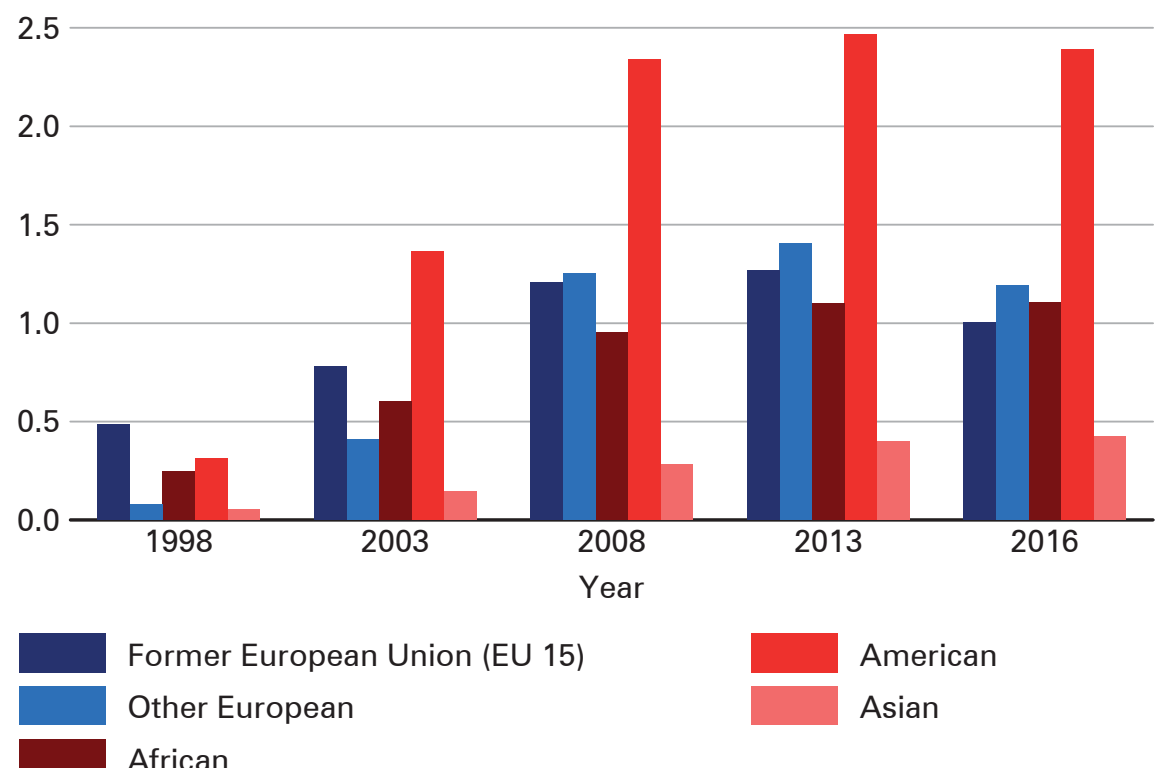

Former European Union (EU 15)

Other European

American

African

Source: Padrón continuo (continuous municipal population register), Spanish National Statistics Institute (INE)

The large number of migrant entries between 1998 and 2007 not only had a spatial impact on large urban regions and their main settlement areas (Bayona/GilAlonso 2012), but also on the rest of the country, including rural areas (Bayona/ Gil-Alonso 2013). Indeed, immigrants usually migrated from municipalities where they first settled to other areas of the country. They either joined "intrametropolitan" residential mobility flows (changes of residence within the same urban area), "intraprovincial" ones (internal migration ${ }^{12}$ from the province's urban area to other municipalities of the same province) or "interprovincial" ones (between different province municipalities).

$\overline{12}$ This paper uses "residential mobility" and "change of residence" as a synonym of "migration" and more specifically, of "internal migration" (residential moves within the borders of a country). However, some authors (for example, Palomares-Linares et al. 2017) distinguish between "residential mobility" and "migration": The first concept would refer to changes of residence that do not imply a significant change of living space. This is equivalent to "intrametropolitan migration" - which takes place within a metropolitan/urban area/region (concepts which will also be used here as synonyms and equivalent to Eurostat's FUA). The second concept, "migration" would imply that migrants do change their living space - in such cases, "migration" can be internal or international. 
These migration flows are not random - they follow intensity, direction, and concentration or dispersion patterns which numerous researchers have intended to conceptualise in recent decades. The literature shows, for instance, that foreign immigrants tend to have high internal migration rates compared to the population as a whole. As observed in Spain (Bayona/Gil-Alonso 2016; Gil-Alonso et al. 2015; Recaño/De Migue/ 2012), their sociodemographic characteristics (younger, on average, than natives and living in different family structures than them) and the fact that they tend to change residence more easily than locals, particularly in the period just after their arrival (Bélanger 1993; Newbold 1996; Rogers/Henning 1999; Zorlu/ Latten 2009), create low labour and residential stability. From a geographical point of view, their internal migration patterns are also different from those of the native population, because they change residence more frequently for labour-related reasons (Musterd 2005).

Researchers agree that internal migration shapes human settlement patterns (Rees et al. 2017). However, there is disagreement on the spatial and social consequences of foreign migrant settlement patterns. Concepts such as concentration versus dispersion, and segregation versus assimilation, have generated much theoretical debate in recent decades, and foreign immigrant's settlement patterns have even been used to measure their level of integration in the host society (Musterd 2003). ${ }^{13}$ For instance, the spatial assimilation theory (Massey/Denton 1985) argues that foreign-born immigrants disperse throughout the receiving country from their initial settlement location - where immigrants of certain nationalities or ethnic groups concentrate - towards other areas in which they are less present. As immigrants progress socioeconomically and strengthen their ties with the host society, they increasingly avoid living in ethnic concentrations.

This theory has been confronted by others. The segmented assimilation theory (Portes/Zhou 1993) sustains that different groups of immigrants can integrate in different ways and at different rhythms in the host country. Furthermore, the ethnic enclave theory suggests that certain immigrants - including socioeconomically successful ones - may prefer to remain in (or migrate to) areas with high proportions of immigrants, where they obtain benefits from existing social networks (Damm 2009). In short, the theoretical background, a priori, could justify both dispersion dynamics (involving both the suburbanisation of foreign immigrants ${ }^{14}$ and their internal net migration from metropolitan areas to the rest of the country) and concentration

13 Similarly, some research projects on vulnerable neighbourhoods have considered high percentages of certain groups of foreigners as an indicator of vulnerability ( $\mathrm{Ne} / \cdot / \mathrm{o}$ et al. 2014).

14 Studies by Bayona/López-Gay (2011) and Bayona/Gil-Alonso (2012) on the Metropolitan Region of Barcelona, by Pozo-Rivera/Rodríguez-Moya (2018) on the Community of Madrid, and by Pujadas et al. (2015), which also includes the cases of Valencia and Seville, show that internal migration of foreign immigrants has played a particularly relevant role in deconcentration processes from core cities to peripheries. Analyses focusing on the mobility patterns of certain nationalities, such as Romanians and Bulgarians (Viruela 2016), Latin Americans (Gil-Alonso et al. 2012), or Moroccans (Pumares 2005; Capote 2012), show that Asians and Africans have the highest internal mobility rates, while Europeans - especially Western European EU citizens - have low rates similar to those of Spaniards, the least mobile population. 
dynamics (implying urban recentralisation). In addition, the theoretical framework could also explain why different geographical origin groups have opposite trends.

Focusing now on large Spanish urban areas, the literature shows that no ghettos (areas where a single ethnic origin group dominates) emerged in Spain during the intense migratory growth years. However, large metropolises do have concentration spaces (Sabater et al. 2013) or areas in which the proportion of immigrants is above the metropolitan average. Given that the tendency to segregation is not uniform (Galeano et al. 2014), certain immigrant groups have created these areas more readily than others have. Asians and Africans, and to a lesser extent Western Europeans, have the greatest tendency towards concentration (Sabater et al. 2012). By contrast, Latin Americans have the greatest tendency towards dispersion and, consequently, the least towards segregation (Gil-Alonso et al. 2012).

However, research - especially Spanish - has given less attention to how economic crises have affected internal migration, particularly that of foreign immigrants. Recaño and Cabré (2003) identified two effects of regressive economic cycles on internal migrations: the reduction of interregional flow intensity, which is consistent with what Courgeau (1985) indicated, and the emergence of regional differences depending on the economic cycle. Certain regions that attracted immigrants during the expansion phase subsequently pushed them back in the economic crisis years, and vice versa.

Based on the existing literature, our hypothesis for this paper is that migration flows of natives and immigrants vary when economic circumstances change (expansion, crisis, and recovery phases). This can be observed at different spatial scales, i.e. moves between urban cores and peripheries, between urban areas and the rest of Spain, and between the FUAs and abroad, affecting each of the migrant group's concentration and dispersion trends. We consider that changes in population stocks and migration flows deserve to be analysed in greater depth and in greater spatial detail, because settlement patterns have multiple relevant implications. As the extensive international literature has shown, some of the most important implications are: the creation and consolidation of migratory networks; immigrant labour, social and cultural integration; growing and shrinking cities; changes in household and population structures; spatial segregation and social polarisation dynamics, and the design and implementation of public policies. ${ }^{15}$

\section{$3 \quad$ Results (I): Migration flow changes}

Data from the Residential Variation Statistics (EVR) are used to describe net migration (the difference between inflows and outflows) by continental origin in the five

15 See, for instance, Bélanger (1993), Frey (1996), Newbold (1996), Rogers/Henning (1999), Borjas (2006), Zorlu/Latten (2009), Kabish/Haase (2011), Randolph/Tice (2014), Rérat (2012), Sharkey (2012), Tyrrell/Kraftl (2015), Bonvalet et al. (2016); Musterd et al. (2016), Bailey/Minton (2018), Hochstenbach/Musterd (2017), Florida (2017), Clark (2017), Vale/Malheiros (2017), Wolff (2018), Wolff/Wiechmann (2018), Smith (2019), or Azpitarte et al. (2019), among others. 
FUAs under study. Net migration is analysed at three different geographical levels, i.e. movements between urban cores and peripheries, those to and from the five FUAs to the rest of Spain, and finally, those between the FUAs and abroad. The commonalities and specificities of these urban areas will be introduced in the following.

\subsection{Internal net migration between core cities and periphery municipalities of the five FUAs}

The five core cities lose Spanish-born inhabitants moving towards their peripheries (Fig. 7). In other words, suburbanisation predominates among Spaniards throughout the analysed period (2005-2016). Nevertheless, suburbanisation starts to decrease in 2007 because of the economic crisis, reaches its minimum in 2015, and picks up again slightly the following year.

Initially, suburbanisation is also dominant among foreign migrants, particularly among those born in the Americas (Fig. 7), who are overwhelmingly Latin Americans and will be called "(Latin) Americans" in the following. These flows towards

Fig. 7: $\quad$ Net migration between the five FUA urban cores and their peripheries (intrametropolitan flows) by place of birth, 2005-2016

Net migration flows in units

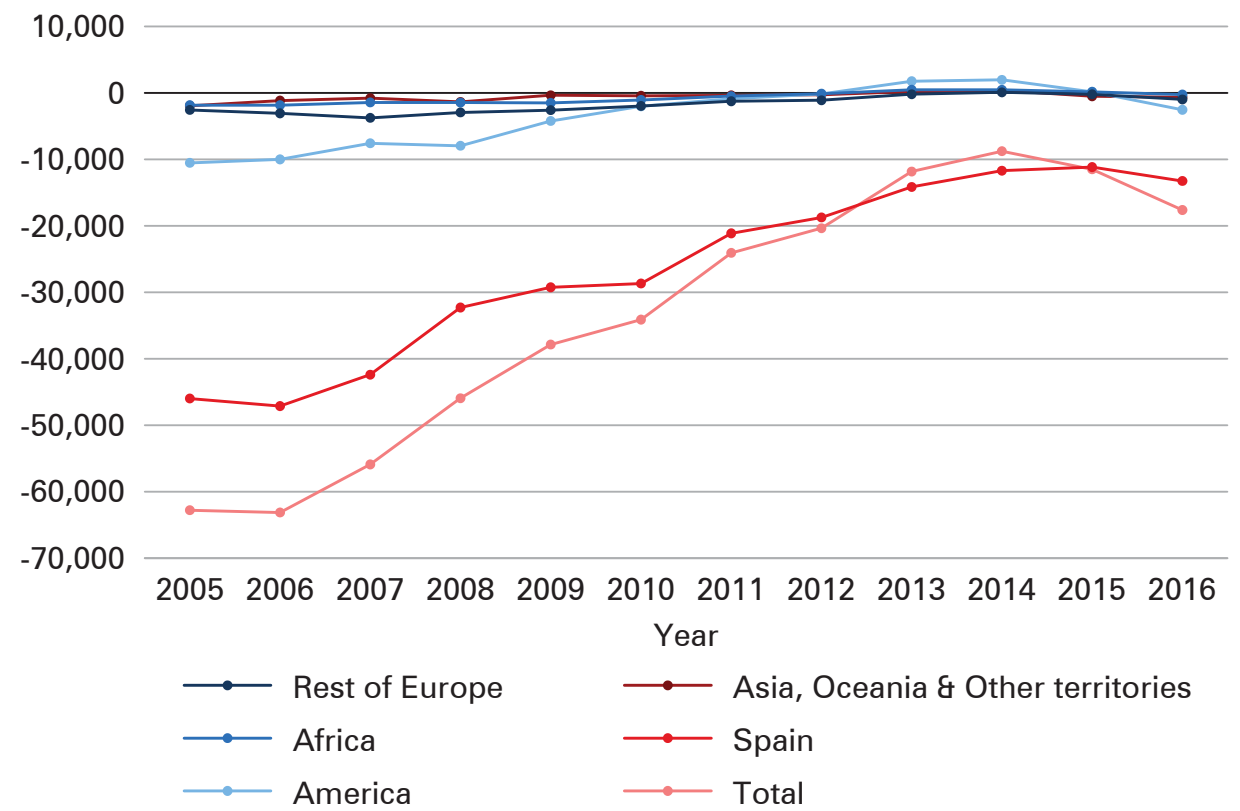

Note: Negative intrametropolitan net migration growth means that suburbanisation is predominant while positive net migration growth indicates that recentralisation is more significant. Net migration flows in units, i.e., $-20,000$ means that, in 2011 , twenty thousand net migrants born in Spain moved from cores to peripheries (same for figures 8 to 11).

Source: Residential Variation Statistics (INE) 
peripheries slow down, again as a result of the economic crisis. (Latin) Americans even end up initiating a recentralisation process in 2013 and 2014. Nevertheless, from 2015 onwards, as the economy improves, suburbanisation also recovers.

\subsection{Internal net migration between each of the five FUAs and the rest of Spain}

In the following paragraphs, the analysis will focus on internal migration flows between these five metropolises and municipalities located in the rest of Spain. Initially, the paper will examine moves from and to the five core cities (Fig. 8, top graph) and then flows to and from peripheries (Fig. 8, bottom graph).

The economic crisis is also a turning point for internal net migration between the five cities and municipalities outside their metropolitan areas. However, it changes in the opposite sense to intrametropolitan moves. Indeed, in the case of people born abroad, net migration between the five core cities and the rest of Spain is initially positive. In other words, there is an initial concentration phase. Then, from 2012 to 2014, flows become slightly negative, beginning a dispersion period. Migrants probably move in search of mainly low-skilled jobs in other parts of Spain less affected by the recession. The only immigrant group that is not affected are Asians. Their internal net migration is positive throughout the entire period analysed (Fig. 8, top graph). By contrast, (Latin) American and European flows have the strongest fluctuations caused by economic changes. Finally, since 2015, immigrant flows between core cities and the rest of Spain have once again become positive, indicating that foreigners are concentrating once more.

In the case of Spaniards, internal net migration between urban cores and the rest of Spain is initially negative. Therefore, natives have a first dispersion phase similar to suburbanisation, but at longer distances. Then, because of the economic crisis, flows start to change. In 2009, the internal net migration of the Spanish-born reaches equilibrium and, from 2011 onwards, it becomes increasingly positive. In other words, driven by economic recession, Spaniards, especially high-skilled ones (González-Leonardo et al. 2019), begin to concentrate in large cities, possibly because their labour markets are larger and more diverse, offer more skilled jobs, and have lower unemployment levels than medium- and small-sized towns. Surprisingly, the current economic recovery does not seem to affect these flows, as natives continue to concentrate in large cities and have not initiated a new dispersion phase.

Fig. 8 (bottom graph) shows internal net migration between metropolitan peripheries and the rest of Spain. Immigrants follow similar patterns to those formerly observed in cores. Initially, metropolitan peripheries attract foreign immigrants but then, during the 2012-2014 deepest economic crisis phase, internal net migration becomes negative (dispersion). Once again, Asians are the only exception. More recently, since 2015, foreigners from the rest of Spain are once more being attracted by the suburban municipalities of the five FUAs.

Yet, in the case of Spanish people, net migration between these peripheries and the rest of Spain is initially negative. Dispersion then diminishes because of the economic crisis, indicating that metropolitan peripheries become increasingly at- 
Fig. 8: Net migration between the five FUA urban cores and the rest of Spain (top) and between the metropolitan peripheries and the rest of Spain (bottom) by place of birth, 2005-2016

Net migration flows in units

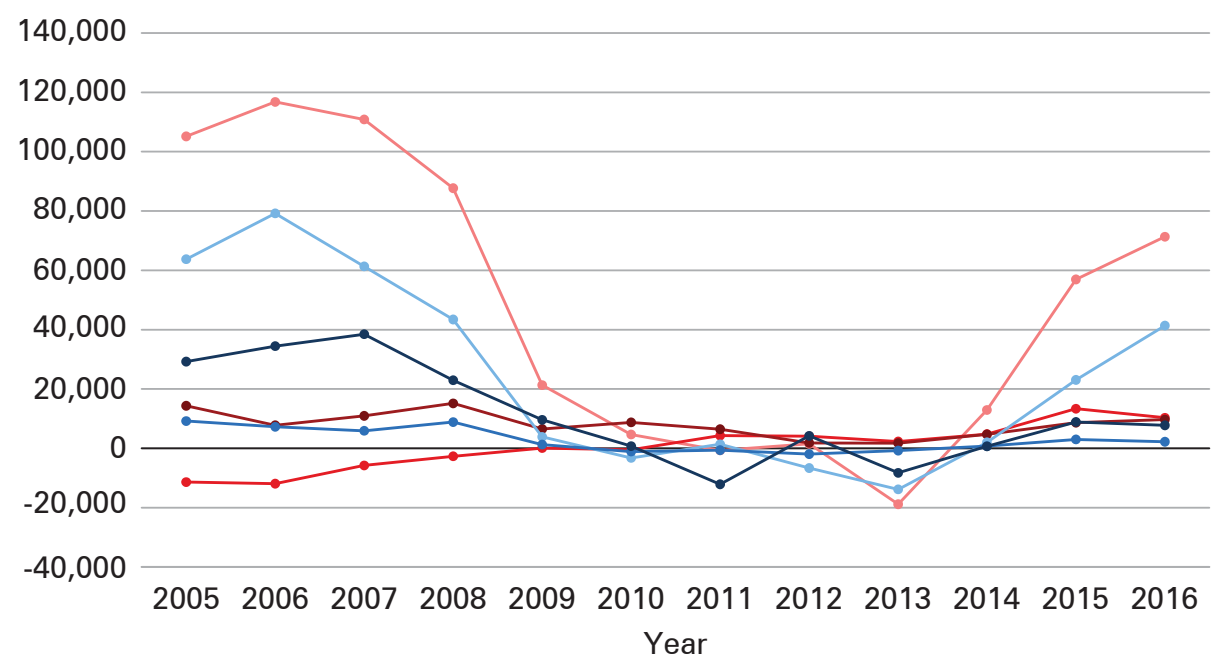

Net migration flows in units

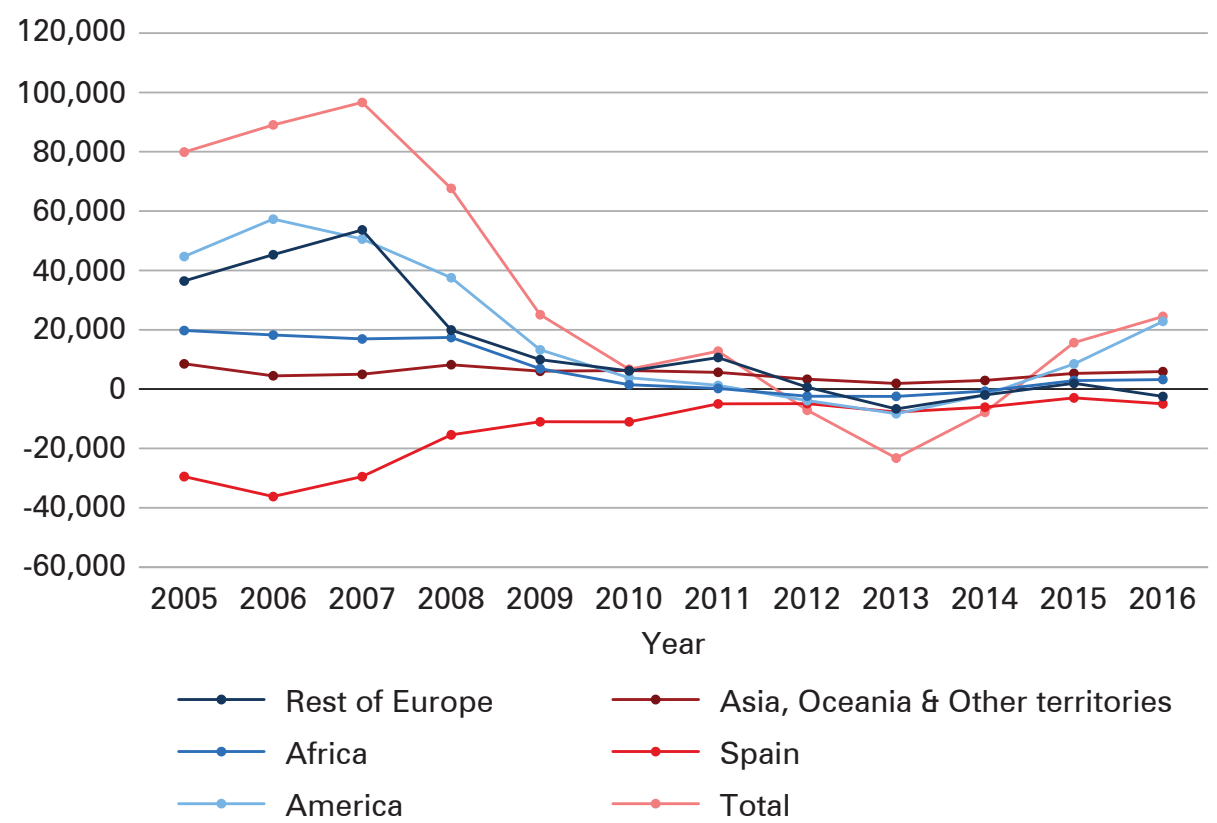

Note: Positive internal net migration growth means that population concentration is predominant in large urban areas while negative net migration growth indicates the opposite, that is to say, that population tends to disperse throughout the rest of Spain.

Source: Residential Variation Statistics (INE) 
tractive. Nonetheless, unlike for the five core cities, in this occasion, net migration is always negative.

\subsection{International net migration between the five FUAs and abroad}

Figure 9 shows international net migration between the five core cities and other countries (top graph) and between the five rings and abroad (bottom graph). Both patterns are very similar, therefore we analyse them together. Once again, people born in Spain and those born abroad behave differently. Economic expansion attracts foreign-born immigrants to large cities, and subsequently their international net migration becomes extremely positive. However, that of natives becomes progressively negative, despite being initially balanced. Not only does the emigration of Spaniards continue during the economic crisis years, but certain foreign-born groups such as (Latin) Americans and Europeans (excluding those born in Spain) also shift to net emigration. Because of the economic crisis, both groups of migrants would be either returning to their countries of origin or moving to third countries. By contrast, international net migration of Africans and Asians is always positive throughout the entire period analysed. In other words, people from these regions of origin are always attracted to the large Spanish urban areas, even during the deepest recession years, and they do not return in large numbers to their countries of origin. Finally, from 2015 onwards, because of the economic recovery, international net migration of all foreign-born groups has become positive once again. That of natives remains negative, though less.

Figure 10 summarises net migration between the five FUAs (urban cores and peripheries together) and other areas, adding up flows from and to the rest of Spain and those from and to other countries. At first glance, it can be observed that total net migration of Spanish-born nationals between the five FUAs analysed and other areas (the rest of Spain and abroad) is always negative, though this population loss becomes less pronounced over time. In 2016, it is almost 10 times smaller than in 2006. It should also be recalled that, despite large cities tending to attract native people from the rest of Spain, net flows with other countries are still negative.

Foreigners' migrant behaviour is strongly conditioned by economic cycles. Indeed, during the economic expansion phase, total net migration between the five FUAs and other areas outside them is positive - large metropolitan areas tend to attract foreign immigrants. It then becomes negative during the economic crisis (particularly between 2012 and 2014), as foreigners are inclined to leave large urban areas and migrate abroad or to the rest of Spain in search of work. However, from 2015 onwards, because of economic recovery, total net migration turns positive once more. Fluctuations of (Latin) American flows are particularly noteworthy as the origin group with the most significant positive total net migration during economic growth phases, and the most relevant negative net-flow in recession periods. At the other end of the spectrum, Asians are the only other exception to foreigners' general mobility patterns as their total net migration remains positive throughout the period analysed. They are permanently attracted to Spain's large metropolitan areas. 
Fig. 9: Net migration between the five FUA urban cores and abroad (top) and between the five FUA metropolitan peripheries and abroad (bottom), by place of birth, 2005-2016

Net migration flows in units

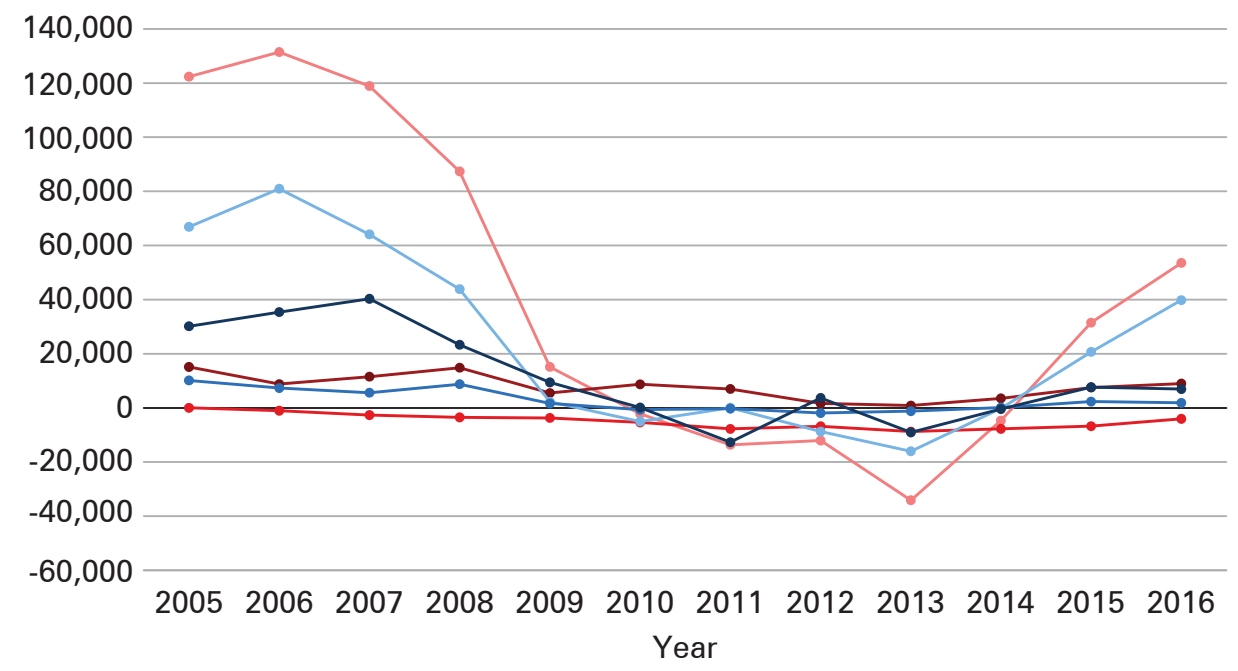

Net migration flows in units

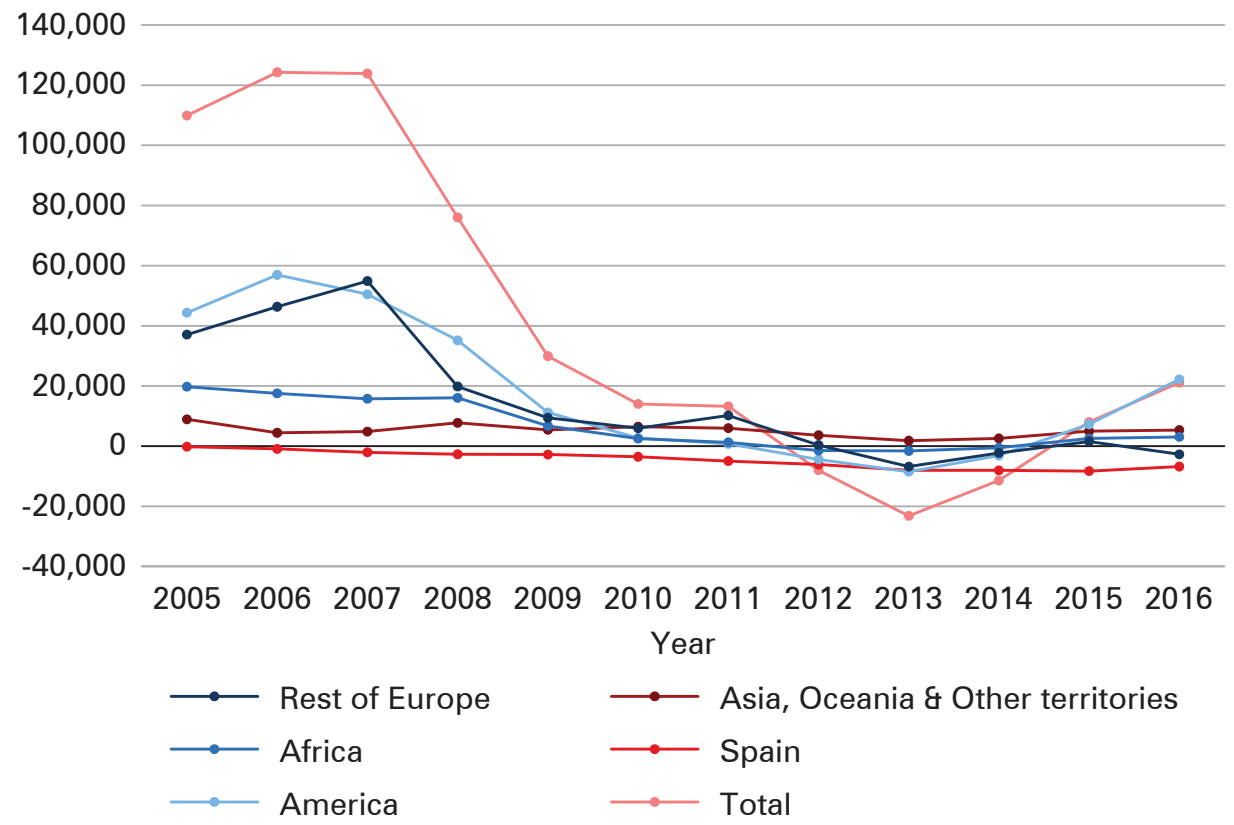

Note: Positive international net migration growth means that there are more inflows to large urban areas from abroad than outflows from large urban areas to abroad. Negative international net migration growth indicates the opposite.

Source: Residential Variation Statistics (INE) 
Fig. 10: Net migration between the five FUAs (urban cores and peripheries together) and other areas (the rest of Spain and abroad), by place of birth, 2005-2016

Net migration flows in units

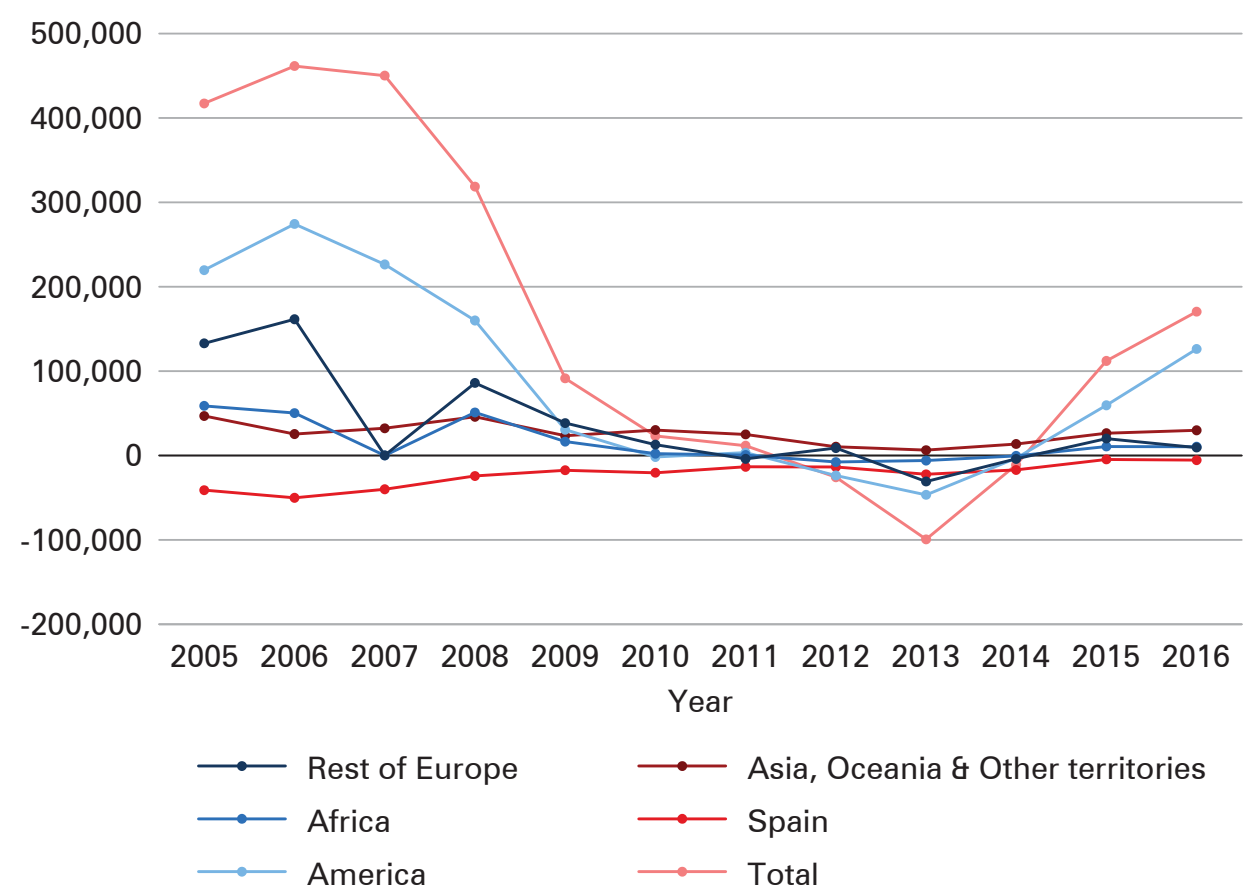

Note: Positive total net migration growth means that there are more inflows to large urban areas from the rest of Spain and abroad than outflows from large urban areas to the rest of Spain and abroad. Negative net migration growth indicates the opposite.

Source: Residential Variation Statistics (INE)

In sum, 2012, 2013, and 2014 are the only years in which total net migration is negative, in the five FUAs. Before 2011 and after 2015, positive migration growth from the rest of Spain and abroad contributes to their population growth. Nevertheless, foreigners leaving Spain are underreported (Gil-Alonso 2010). Therefore, positive net migratory growth is probably somewhat lower in economic expansion years, and negative net growth higher during crisis years.

\subsection{Specific features of each of the five FUAs}

Figure 11 shows the total net migration between each of the five FUAs and rest of Spain and abroad, allowing for the analysis of each FUA's particularities. In general, they all show similar mobility patterns, though some differences are worth spelling out: 
Fig. 11: Net migration between each of the five FUAs (urban cores and peripheries together) and the rest of Spain and abroad, by place of birth, 2005-2016

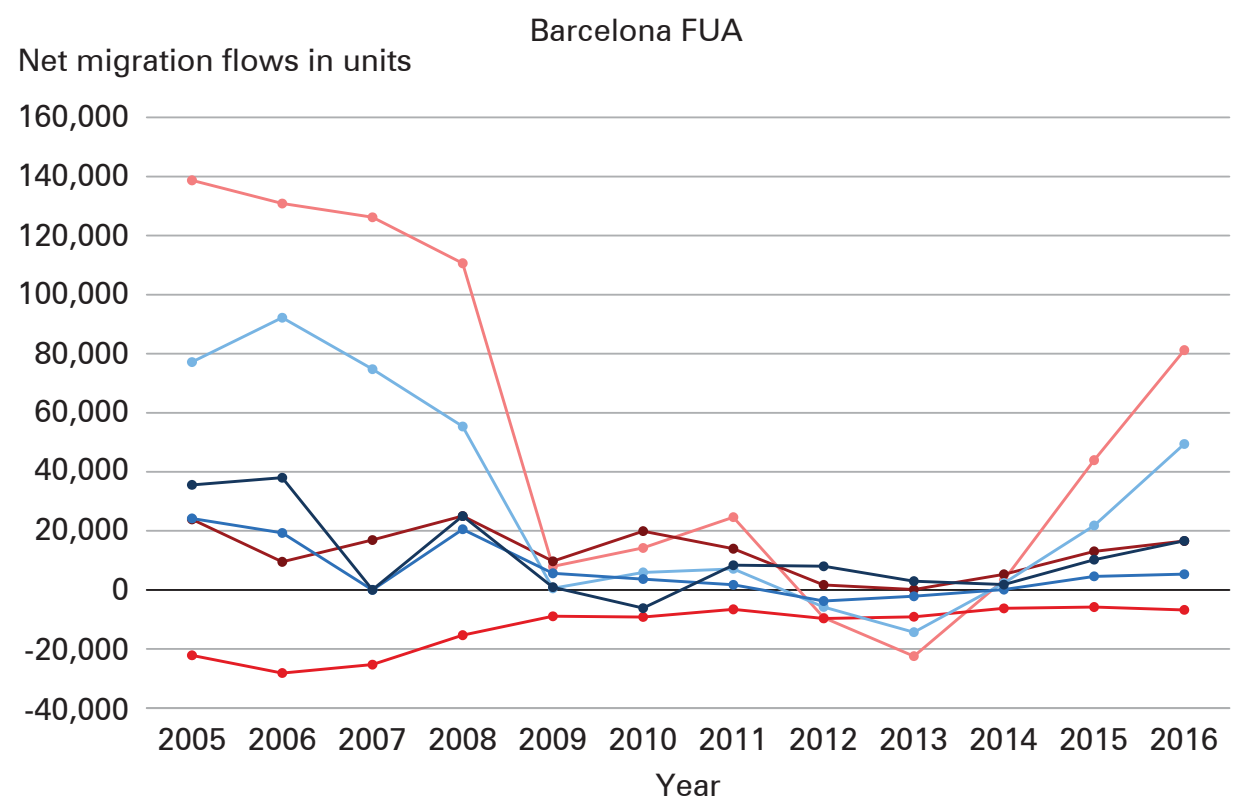

Net migration flows in units

Bilbao FUA

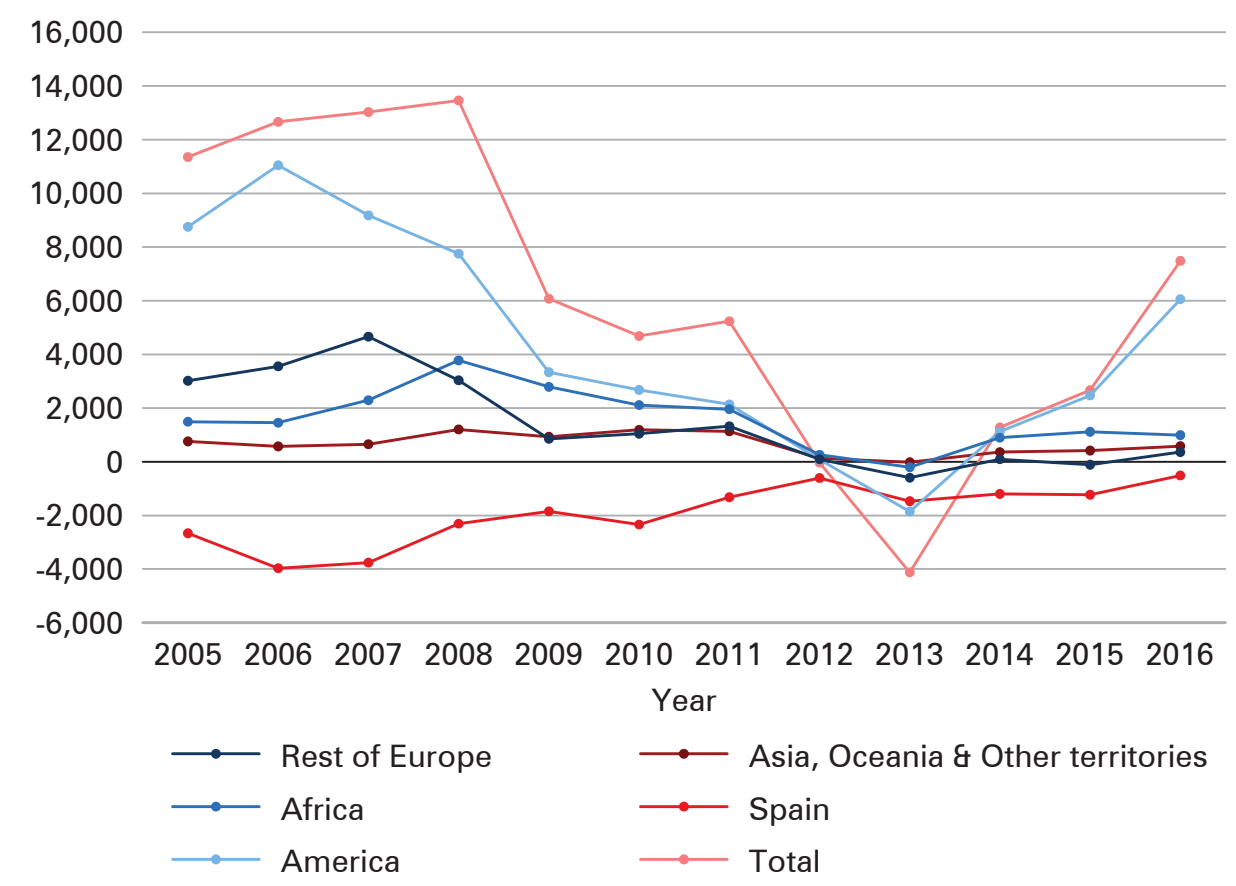


Fig. 11: Continuation

Net migration flows in units

Madrid FUA

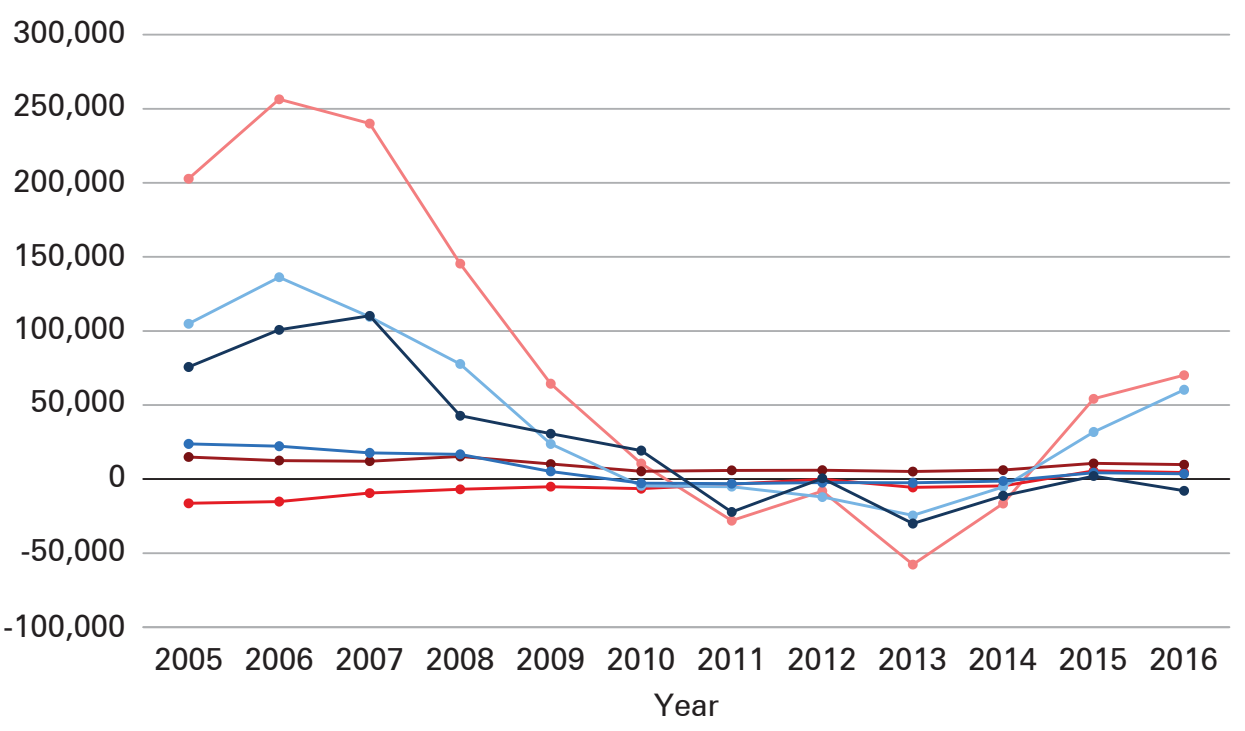

Net migration flows in units

Seville FUA

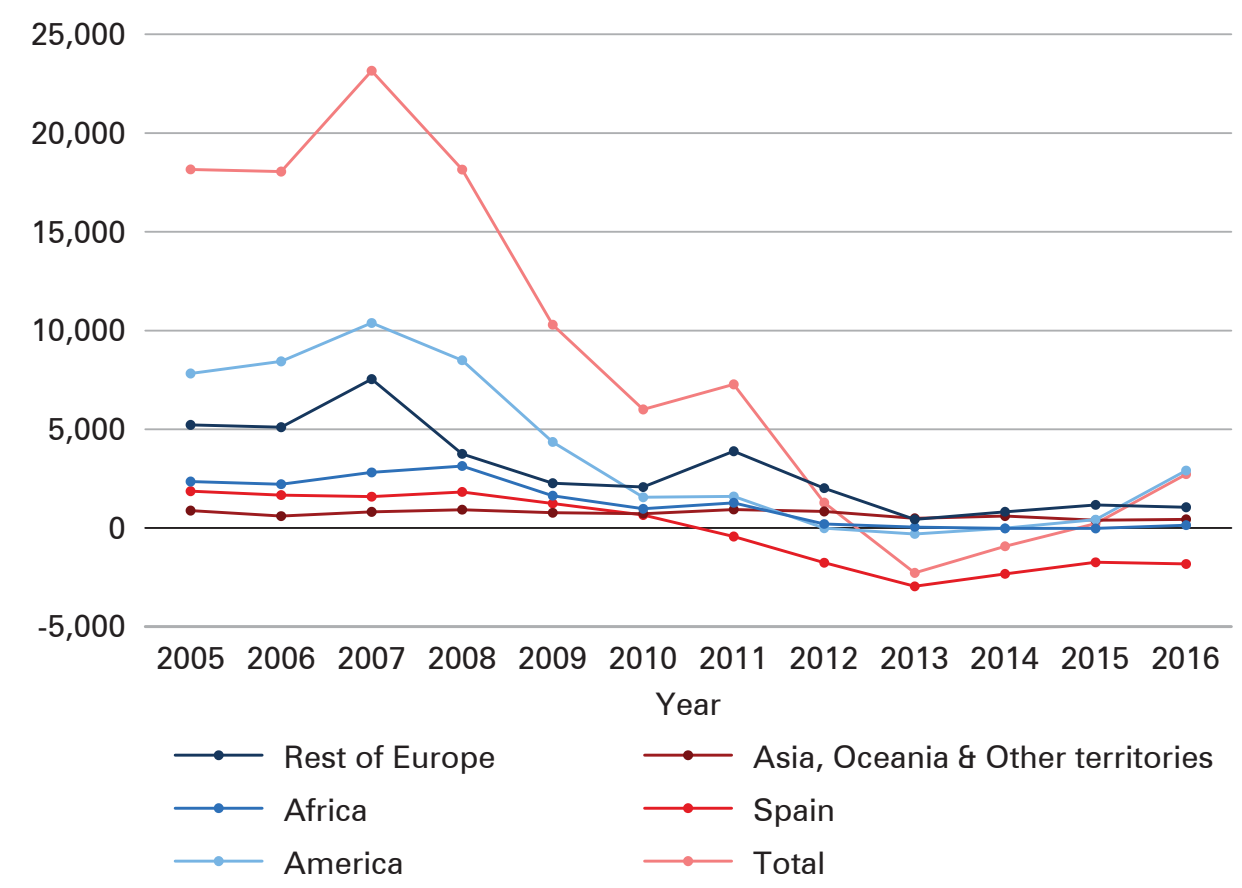


Fig. 11: Continuation

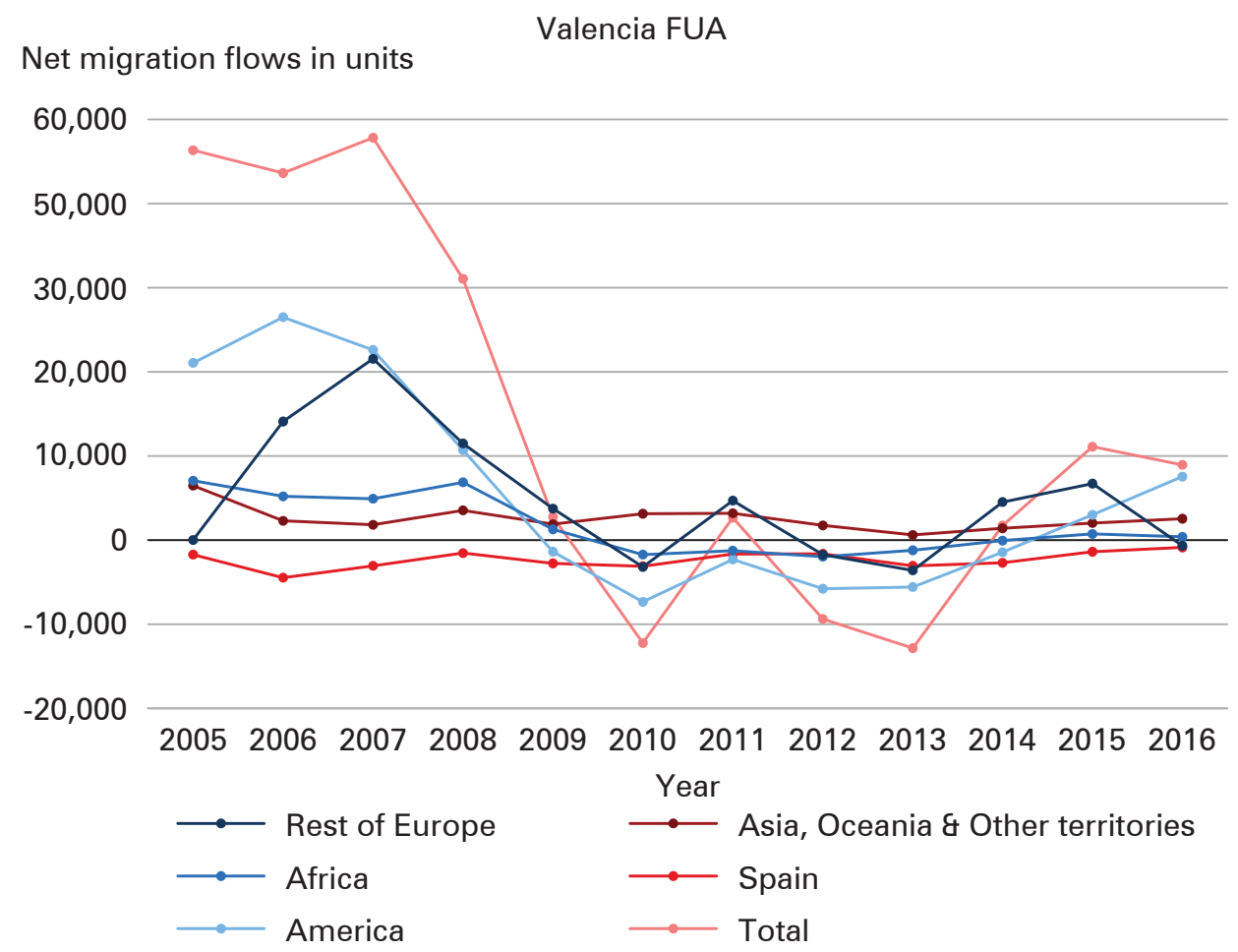

Source: Residential Variation Statistics (INE)

- Barcelona FUA: The foreign groups least affected by the economic crisis are Asians and Europeans. By contrast, (Latin) Americans were the most affected. However, in 2015-2016, (Latin) Americans' total net migration was again strongly positive. For natives, total net migration is always negative.

- Bilbao FUA stands out for its extremely negative total net migration among Spaniards. However, it is slowly approaching equilibrium. Once again, the group most affected by the economic crisis are (Latin) Americans, though it is also true that Bilbao is the city in which the economic recession has had less dramatic effects, as 2013 is the only year in which total net migration of foreigners is clearly negative.

- Madrid FUA: As opposed to Bilbao, Madrid is the FUA in which total net migration of Spanish-born nationals is less negative. In fact, it is the only FUA in which total net migration of natives has been positive since 2015. As in Barcelona FUA, the total net migration of foreigners also recovered after the economic crisis, though not as significantly.

- Seville FUA seems to show some delay with respect to the other four. Though the effects of the economic crisis are already visible in 2009 and 2010 in Barcelona, Madrid and Valencia, they do not feature in Seville until 2012. In addition, until 2016 Seville FUA shows little signs of economic recovery. It also stands out for being the only FUA in which total net migration of Spaniards is positive until 2010; then, it becomes clearly negative. 
- Valencia FUA is where the economic crisis lasts longest, affecting flows between 2009 and 2013 - Valencia and its region was particularly hit when the "housing bubble" burst. Recovery starts to be visible in 2014; net migration flows grow faster than in Seville, but more slowly than in the other three Functional Urban Areas.

\section{$4 \quad$ Results (II): Population stock changes}

As mentioned above, the continuous municipal population register or Padrón which indicates each municipality's official population on January 1st of each year - has been used as a main data source to analyse stock changes during the 20052016 period both for natives and people born abroad. Population stock changes not only incorporate variations due to migration but also those due to natural changes (the balance of births minus deaths). Nevertheless, in recent years, the five urban areas analysed - and their respective core cities ${ }^{16}$ - show minimal natural in- and decreases. Consequently, population stock changes depend almost exclusively on migratory flows - this is particularly true in the case of foreign-born people - and, therefore, growth is very sensitive to economic cycle fluctuations. Indeed, Padrón data show that the five main Spanish FUAs gained population during the economic boom years, but that the economic recession changed this trend. Initially, all the five FUAs continued to grow, though at a lower rate. In 2012, four started to lose population. Barcelona and Valencia decreased until 2014, Madrid until 2015, and Bilbao until 2016. Seville is the only exception, as its population remained stable during the years under examination. Population figures started to recover in 2015 and 2016, with the exception of Bilbao, which still had slight negative growth in 2016.

If only cores are analysed, the five main cities' populations decreased during the crisis period, losing inhabitants between 2009 and 2014 in Barcelona, until 2015 in Valencia, and until 2016 in Bilbao. The same occurred in Madrid, but from 2010 to 2015, and until 2016 in Seville. In other words, in 2016 the cities of Barcelona, Madrid and Valencia were growing once again, while Bilbao and Seville were not.

Peripheral municipalities also show changes throughout the period analysed. In Madrid and Seville FUAs, they have not stopped growing, though their population has increased less rapidly since 2010 due to the economic crisis. Urban fringe areas in Valencia slightly shrank in 2012 and 2013, as did those of Barcelona in 2013 and 2014. The only exception is Bilbao FUA, as its peripheral municipalities lost population since 2013 and have not recovered it since.

\subsection{Total population stocks in the five FUAs}

In order to capture the impact of economic phases on population growth, we have calculated cumulative annual growth rates for the five FUAs under study (Fig. 12).

16 For instance, in 2016 the cities of Barcelona, Bilbao, Madrid, Seville and Valencia show a natural growth of $-1554,-1287,2353,428$, and -686 inhabitants, respectively. 
Fig. 12: Core city and periphery population changes by place of birth, 20052016: Cumulative Annual Growth Rates (CAGR)
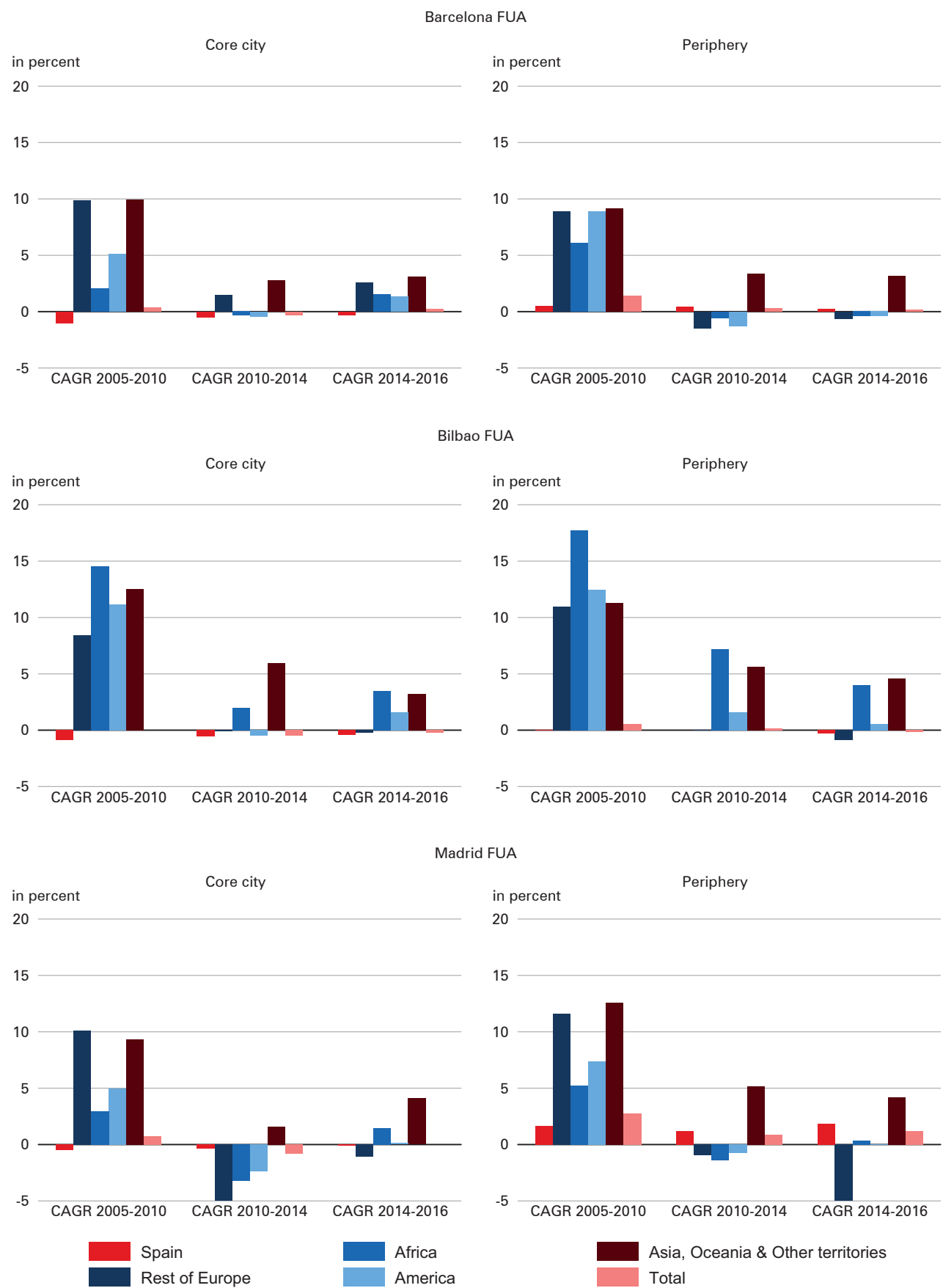
Fig. 12: Continuation

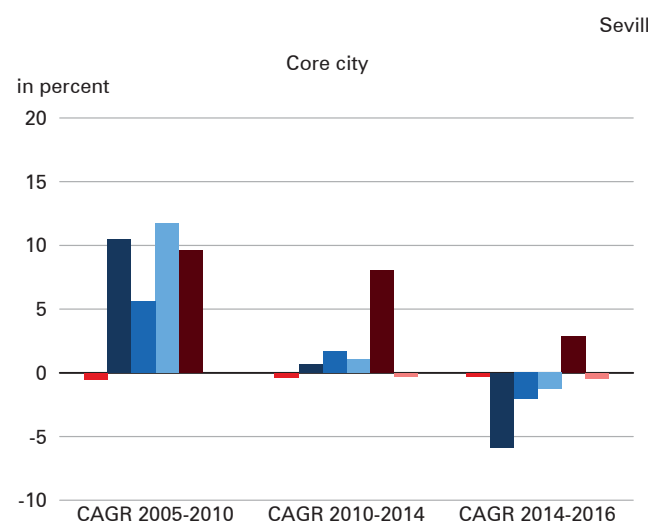

Seville FUA

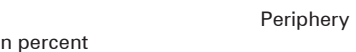
20

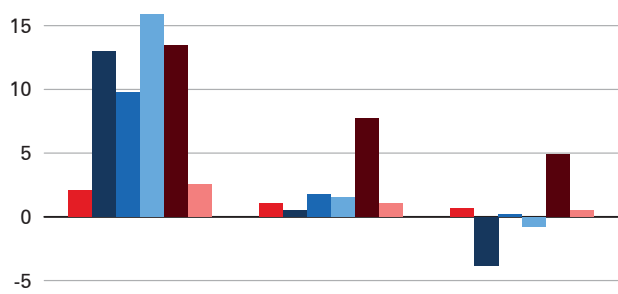
$-5$

CAGR 2005-2010 CAGR 2010-2014 CAGR 2014-2016

Valencia FUA

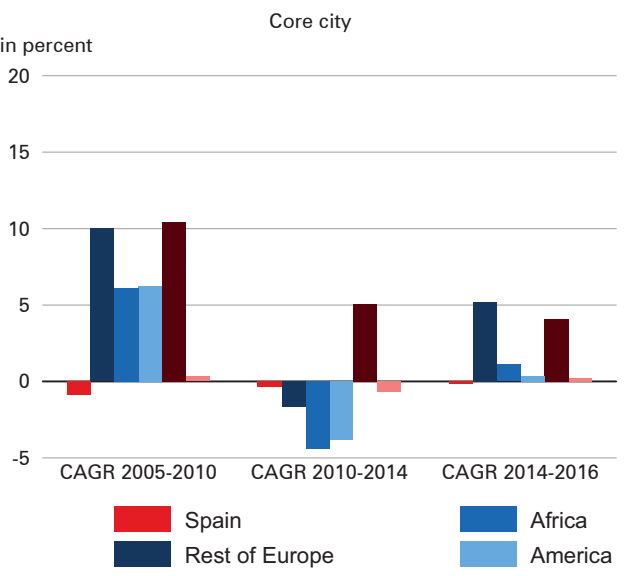

in percent 20

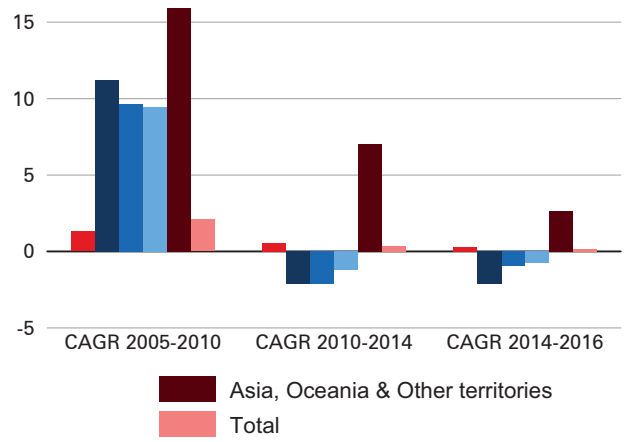

Source: Padrón continuo (continuous municipal population register)

The rates are divided into three periods, that is to say, from $1^{\text {st }}$ January 2005 to $1^{\text {st }}$ January 2010 (the economic boom), from $1^{\text {st }}$ January 2010 to $1^{\text {st }}$ January 2013 (the deep economic crisis) and from $1^{\text {st }}$ January 2013 to $1^{\text {st }}$ January 2016 (the economic recovery). Core cities and peripheries are analysed separately, highlighting the differences between Spanish and foreign-born populations (Fig. 12).

\subsection{The Spanish population in the five FUAs}

The five core cities lose Spanish-born inhabitants throughout the period analysed, though to a lesser extent during the economic crisis years than in the economic boom years. In other words, recession slowed down Spanish-born population loss in the five FUAs. Furthermore, according to available data, Madrid is the only city 
that does not lose Spanish-born population in the last period analysed - as we have explained, it has both positive internal net migration and positive natural growth.

The results for peripheral municipalities are different. Four of the five suburban areas gained Spanish-born population throughout all periods under study. However, the economic recession had a deep impact on them, largely reducing their growth. The only exception is the Bilbao FUA, as the Spanish population of its suburban municipalities decreased in both the expansion and crisis phases.

As a whole (taking cores and rings together), the five FUAs show similarities. Indeed, four of them gained natives throughout the periods analysed, the exception being Bilbao, as its population born in Spain constantly decreases.

\subsection{Population born abroad (by continental origin) in the five FUAs}

During the economic boom years, the foreign-born population increased in both core cities and peripheries in all metropolitan areas examined. Asians were the only foreign group that grew consistently, even during the economic crisis period. The other four immigrant groups were, to a greater or lesser extent, affected by economic changes. In this sense, (Latin) Americans and Europeans were the hardest hit, as their numbers decreased during the recession phase. Africans in the Bilbao FUA and Europeans in the core cities of Barcelona and Valencia also show a distinctive behaviour. In the first case, they grew during the entire economic crisis period, and in the latter, they increased from 2014 onwards.

\section{Discussion and conclusions}

Research results show that suburbanisation (more people moving from cores to rings than vice versa) was the predominant "intrametropolitan" migration flow between the five urban cores and their peripheries during the economic expansion phase. This phenomenon was particularly important for natives and for people born in the Americas (mainly Latin Americans). In general, foreign migrant suburbanisation trends are in line with the spatial assimilation theory (Massey/Denton 1985). However, the fact that suburbanisation intensity is not homogeneous throughout all the groups analysed - Africans even tended to increase their segregation levels over time (Bayona/López-Gay 2011) - would instead validate the segmented assimilation theory (Portes/Zhou 1993).

These flows to the suburban periphery decreased during the economic crisis, and in 2013 and 2014, net intrametropolitan migration of most foreign groups Latin Americans in particular - even became positive (i.e. more recentralisation than suburbanisation). Spaniards' intrametropolitan flows were never positive, but they almost reached equilibrium during the recession years - natives decreased their moves from cores to rings, while they were increasingly attracted to urban centres. Several elements might explain why core cities lost less and gained more Spanish-born and foreign-born residents during the economic crisis. Large housing developments in suburban towns stopped being built when the real estate bubble 
burst and banks restricted new mortgages. While access to property ownership became increasingly difficult, urban cores became more attractive. They have larger rental housing stocks, more and the best-paying jobs, and better public transport networks, which implies that commuting costs are lower in dense cities than in the periphery. All these factors - and not the ethnic enclave theory (Damm 2009) would in our opinion explain why recentralisation, rather than non-suburbanisation, seems to have been a more logical option for both natives and immigrants during economic recession.

Owing to the economic recovery from 2015 onwards, intrametropolitan migration flows have become negative once again and suburbanisation is progressively returning to its previous levels. If this trend consolidates (as 2017 and 2018 data seem to confirm), the relative recentralisation during the deepest economic recession years will have basically been a cyclical (or punctual) event.

As for other types of residential moves, foreign-born immigrants moving from abroad and the rest of Spain to the five FUAs during the economic expansion phase inverted the direction of their flows in the economic crisis years, migrating abroad or dispersing throughout Spain in search of jobs. Consequently, their stocks reduced during some years - the only exceptions being Europeans in Barcelona and Asians in all five areas. Finally, due to the incipient economic recovery, the five FUA are now attracting immigrants once again, so their foreign-born population stocks are currently increasing in both cores and peripheries.

Spanish-born people show the opposite behaviour regarding flows from and to the five areas analysed. They tended to disperse throughout the rest of Spain during the economic expansion phase, therefore showing negative internal net migration rates. This negative trend continued during the crisis years, but at a slower pace, as natives became increasingly attracted to urban cores. Furthermore, this latter trend has strengthened during the post-crisis years. Two cases stand out. First, the city of Madrid is the main destination of young native migrants (González-Leonardo et al. 2019) and is the only area analysed in which internal net migration of Spaniards is currently positive. Second, Seville FUA shows the opposite tendency. In other words, Seville FUA mostly attracted Spanish people during the expansion phase, but Spanish-born internal net growth is clearly negative in the crisis and post-crisis stages.

Considering foreign-born and Spanish populations together, large urban areas are increasingly attractive. This global tendency is to the detriment of rural areas and of non-metropolitan small and medium size towns, which lose population because of negative internal net migration. Out-migration of (mainly skilled) young people who move to large cities in search of greater educational and employment opportunities is particularly problematic.

Finally, the five FUAs lose Spanish-born inhabitants emigrating abroad during the entire period studied, though in comparison to deepest economic recession years, this negative international net migration is currently receding.

Obviously, these general results contain interesting differences between the diverse geographical origin groups of immigrants, and between the five urban areas analysed. Latin American flows and stocks have been affected the most by econom- 
ic changes: large numbers of these migrants move to or leave Spain's urban areas depending on whether the economic situation is expansive or recessive, respectively. Their easy access to Spanish citizenship can probably explain their labour and migratory flexibility. ${ }^{17}$ Therefore, Latin American flows would, using Massey's (1988) words, "serve as a buffer" for current economic processes. European immigrants - many of them EU citizens - show similar, though less marked, patterns. Meanwhile, African flows and stocks show the opposite migratory behaviour - they try to remain in Spain's metropolises and their emigration flows are never too large, not even during hard times. Finally, Asian flows and stocks are constantly growing, regardless of the period analysed-expansion, crisis or post-crisis - and are the least affected by economic cycles.

Despite similarities in the population dynamics of the five FUAs, certain differences should be pointed out. Madrid FUA stands out for attracting Spaniards while Bilbao's Spanish-born population has decreased most drastically. Barcelona is particularly attractive for European migrants. The economic crisis started later in Seville, which is the FUA that currently shows the least signs of economic and population recovery. In addition to this late economic cycle, Seville has less foreign population. These specificities could probably be explained by Seville's lower economic development in comparison to the other four urban areas. Finally, Valencia does not stand out in any respect and presents largely average values regarding migration flows.

These results confirm previous and recent findings by our research group, underlining the role of migration in shaping present urban population structure and dynamics. Indeed, they confirm the relevance of both internal and international migrations in the rejuvenation of certain neighbourhoods such as the historical centres of the cities analysed (Gil-Alonso et al. 2018). These processes coincide with other phenomena such as gentrification and "touristification" (Judd/Fainstein 1999; Florida 2002), increasing inequality, social polarisation and segregation (Florida 2017), and the concentration of certain foreign groups in some parts of the city and the subsequent replacement of certain nationalities by others - though, as has been explained, there are hardly any ghettos in Spain (Sabater et al. 2013).

Interactions between all these phenomena show migration complexity and the diversity of its spatial consequences. Moreover, low fertility and increased life expectancy diminish the relevance of natural growth and emphasise the growing importance of migration in the development of the populations of urban regions across Spain and Europe. However, there are differences according to migrants' origin. Migration flows by Spanish-born people exhibit relatively low intensity and net effects, as most migration flows are balanced by counter-flows, resulting in limited

17 Latin American immigrations and emigrations are facilitated by the Spanish law, which favours the acquisition of Spanish citizenship by nationals of Spain's ex-colonies. Indeed, Latin Americans can acquire Spanish citizenship much more easily (after two years of regular residence in Spain) than other foreigners can. Many Latin Americans have done so, as having Spanish nationality favours their migratory movements, especially when the economic cycle changes. Consequently, they can adapt more easily to economic circumstances. 
population redistribution and dynamic equilibrium. This phenomenon is typically observed in highly-developed countries (Rees et al. 2017). By contrast, foreign-born migrants' international and internal flows are the main factor currently redistributing Spain's urban population. The higher intensity and effectiveness of their mobility is conditioned by economic phases, which change the direction of the in- and out-flows and the (positive or negative) sign of their net migration rates. Indeed, in the dynamic equilibrium context broadly characterising the analysed urban areas, suburbanisation is the dominant process during economic expansion phases, while recentralisation gained more relative importance during the last crisis period - particularly among foreign-born immigrants, whereas suburbanisation of natives decreased in intensity.

Therefore, there are multiple causes of migration, but undoubtedly the economic ones are among the most relevant, at least in the case of the five FUAs analysed. Although the emigration (from Spain) of people born in other countries is underregistered, the data are solid enough to conclude that there have been strong changes in migrant stocks and flows in the five largest Spanish metropolises as a result of economic cycle fluctuations. This corroborates the paper's initial hypothesis - that migrations affecting large urban areas are mainly economically driven, either directly through the labour market, or indirectly, through the real estate market - and confirms the validity of Ravenstein's ideas at the beginning of the $21^{\text {st }}$ century. More specifically, migration changes in the last two decades broadly validate Ravenstein's first, second, third and fourth laws. Indeed, large urban areas remains migrants' main attraction poles, and short-distance flows (suburbanisation, recentralisation) predominate. In general, migration flows still decrease with distance, although transport improvements or "facilities of communication" (Ravenstein 1885: 199) can explain, among other factors, the current importance in Spain of Latin American in- and out-flows.

By contrast, it is currently not true that "the natives of towns are less migratory than those of the rural parts of the country" (sixth law; Ravenstein 1885: 199), as a significant part of migratory moves in developed countries now occurs between urban areas: The decreasing and aged population remaining in rural areas is generally less mobile than urbanites (Greenwood 2019). Finally, the seventh law, that "females are more migratory that males" (Ravenstein 1885: 199), was not tested in this paper. However, literature demonstrates that, presently, women are predominant in the remaining rural-to-urban internal migration - at least in Spain and other developed countries - and in some international flows, though not in others. In Spain, for instance, immigration from Latin America is predominantly female, whereas immigrants from African and most Asian countries are mainly men. However, the present validity of Ravenstein's laws can be corroborated in general terms, demonstrating the precursory and even visionary character of his ideas.

\section{Acknowledgements}

Research for the present paper was conducted within two R+D projects. The first, Desigualdad social, polarización territorial y formación de espacios vulnerables en 
las grandes áreas metropolitanas españolas (Social inequality, territorial polarisation and formation of vulnerable spaces in the largest Spanish metropolitan areas, ref. CSO2015-65219-C2-1-R), was directed by Dr. Isabel Pujadas and Dr. Fernando Gil-Alonso. The second, Nuevas movilidades y reconfiguración sociorresidencial en la poscrisis: consecuencias socioeconómicas y demográficas en las áreas urbanas españolas (New mobilities and socio-residential reconfiguration in the postcrisis: socioeconomic and demographic consequences in Spanish urban areas, ref. RTI2018-095667-B-I00), is directed by Dr. Fernando Gil-Alonso and Dr. Cristina López. Both projects are funded by the Spanish Ministry of Science, Innovation and Universities, the Spanish Research Agency and the European Regional Development Fund (AEI/ERDF, EU). A very preliminary version of this research was presented at the XVI Congreso de la Población en España (Alicante, 2018). The authors, Dr. Fernando Gil-Alonso and Dr. Jenniffer Thiers-Quintana, belong to the Territori, Població i Ciutadania (Territory, Population, and Citizenship) research group of the University of Barcelona, officially recognised by the Catalan government (ref. GRC_2017SGR1298). The authors are grateful for the comments received from Phil Rees, the language editor and the reviewers contributing to improvements in the text.

\section{References}

Abella, Manolo; Ducanes, Geoffrey 2009: Technical note on the effect of the global economic crisis on Asian migrant workers and governments' responses. Bangkok: ILO Regional Office for Asia and the Pacific.

Awad, Ibrahim 2009: The Global Economic Crisis and Migrant Workers: Impact and Response. Geneva: International Labour Office.

Azpitarte, Francisco; Alonso-Villar, Olga; Hugo-Rojas, Felipe 2019: On the Changing Spatial Distribution of Human Capital and Occupation Groups: An Analysis of Recent Trends in Australia's Main Capital Cities. In: Working Paper 19/03. Vigo: Universidade de Vigo.

Bailey, Nick; Minton, Jon 2018: The suburbanisation of poverty in British cities, 2004-16: extent, processes and nature. In: Urban Geography 39,6: 892-915 [doi: 10.1080/02723638.2017.1405689].

Bayona, Jordi; Gil-Alonso, Fernando 2016: Europeos bajo la crisis: Cambios en sus patrones migratorios recientes en España. In: Scripta Nova XX, 549-2.

Bayona-i-Carrasco, Jordi; Gil-Alonso, Fernando 2013: Is foreign immigration the solution to rural depopulation? The case of Catalonia (1996-2009). In: Sociologia Ruralis 53,1: 26-51 [doi: 10.1111/j.1467-9523.2012.00577.x].

Bayona-Carrasco, Jordi; Gil-Alonso, Fernando 2012: Suburbanisation and international immigration: The case of the Barcelona Metropolitan Region (1998-2009). In: Tijdschrift voor economische en sociale geografie/Journal of Economic and Social Geography 103,3: 312-329 [doi: 10.1111/j.1467-9663.2011.00687.x].

Bayona-i-Carrasco, Jordi; López-Gay, Antonio 2011: Concentración, segregación y movilidad residencial de los extranjeros en Barcelona. In: Documents d'Anàlisi Geogràfica 57,3: 381-412. 
Bayona-i-Carrasco, Jordi; Thiers-Quintana, Jenniffer; Ávila-Tàpies, Rosalía 2017: Economic recession and the reverse of internal migration flows of Latin American immigrants in Spain. In: Journal of Ethnic and Migration Studies 43,15: 2499-2518 [doi: 10.1080/1369183X.2017.1296354].

Bélanger, Alain 1993: La migration interprovinciale des personnes nées à l'étranger, Canada, 1981-1986. In: Cahiers Québécois de Démographie 22,1: 153-178.

Bonvalet, Catherine; Bringé, Arnaud; Imbert, Christophe 2016: Urban dynamics and residential trajectories in Paris. In: Portuguese Journal of Social Science 15,1: 25-46 [doi: 10.1386/pjss.15.1.25_1].

Borjas, George J. 2006: Native internal migration and the labor market impact of immigration. In: Journal of Human resources 41,2: 221-258 [doi: 10.3386/w11610].

Capote, Alberto 2012: Inmigración extranjera en la provincia de Córdoba: destino secundario de los inmigrados marroquíes en Andalucía. In: Scripta Nova XVI, 419.

Castles, Stephen 2009: Migration and the Global Financial Crisis: A Virtual Symposium. Update 1.A: An Overview.

Castles, Stephen 2011: Migration, crisis, and the global labour market. In: Globalizations 8,3: 311-324 [doi: 10.1080/14747731.2011.576847].

Castles, Stephen; Miller, Mark J. 2010: Migration and the Global Economic Crisis: One Year On. Update 1.L.

Clark, William A.V. 2017: Residential mobility in context: Interpreting behavior in the housing market. In: Papers de Sociologia 102,4: 575-605 [doi: 10.5565/rev/papers.2411].

Courgeau, Daniel 1985: Interaction between Spatial Mobility, Family and Career LifeCycle: A French Survey. In: European Sociological Review 1,2: 139-162 [doi: 10.1093/ oxfordjournals.esr.a036382].

Damm, Anna. Piil 2009: Ethnic enclaves and immigrant labor market outcomes: Quasi-experimental evidence. In: Journal of Labor Economics 27,2: 281-314 [doi: 10.1086/599336].

Dobson, Janet; Latham, Alan; Salt, John 2009: On the Move? Labour Migration in Times of Recession. In: Policy Network Papers: 1-23.

Eurostat 2017: Methodological manual on city statistics. 2017 edition. Luxembourg: Publications Office of the European Union [doi: 10.2785/708009].

Fielding, Tony 2010: Migration in a Time of Crisis: A simple conceptual framework applied to East Asian migrations. Working Paper 63. Sussex Centre for Migration Research.

Fix, Michael et al. 2009: In: Migration and the Global Recession. Washington DC: Migration Policy Institute.

Florida, Richard 2017: The new urban crisis: How our cities are increasing inequality, deepening segregation, and failing the middle class and what we can do about it. New York: Basic Books.

Florida, Richard 2002: The rise of the creative class. And how it is transforming work, leisure, community and everyday life. New York: Basic Books.

Frey, William H. 1996: Immigration, domestic migration, and demographic balkanization in America: new evidence for the 1990. In: Population and Development Review 22,4: 741-763 [doi: 10.2307/2137808].

Galeano, Juan Martín; Sabater, Albert; Domingo, Andreu 2014: Formació i evolució dels enclavaments ètnics a Catalunya abans i durant la crisi económica. In: Documents d'Anàlisi Geogràfica 60,2: 261-288 [doi: 10.5565/rev/dag.111]. 
Ghosh, Jayati 2009: Will the Crisis Reverse Global Migration? In: Yale Global 14.

Gil-Alonso, Fernando 2010: Análisis de dos propuestas metodológicas para estimar las salidas de extranjeros de España: las bajas por caducidad padronales y la renovación de las tarjetas de residencia temporales. In: Estadística Española 52,174: 277-309.

Gil-Alonso, Fernando; Bayona-i-Carrasco, Jordi; Pujadas, Isabel 2015: Las migraciones internas de los extranjeros en España. Dinámicas espaciales recientes bajo el impacto de la crisis. In: Boletín de la Asociación de Geógrafos Españoles 69: 233-261.

Gil-Alonso, Fernando; Bayona-i-Carrasco, Jordi; Vono de Vilhena, Daniela 2012: Las migraciones internas de los latinoamericanos en España: del boom a la crisis económica. In: Papeles de Población 18,71: 9-50.

Gil-Alonso, Fernando et al. 2018: ¿Hacia unas ciudades segregadas según la edad? Geografía dinámica del envejecimiento y rejuvenecimiento en las grandes metrópolis españolas". In: XVI Congreso de la Población en España. Respuestas geodemográficas a los cambios del modelo socioeconómico. Alicante, 12-14 September.

González-Leonardo, Miguel; López-Gay, Antonio; Recaño, Joaquín 2019: Brain drain and the Second Wave of Depopulation. In: Perspectives Demogràfiques 16: 1-4.

Greenwood, Michael J. 2019: The migration legacy of E. G. Ravenstein. In: Migration Studies 7,2: 269-278 [doi: 10.1093/migration/mny043].

Hochstenbach, Cody; Musterd, Sako 2017: Gentrification and the suburbanization of poverty: changing urban geographies through boom and bust periods. In: Urban Geography 39,1: 26-53 [doi: 10.1080/02723638.2016.1276718].

Judd, Dennis R.; Fainstein Susan S. (Eds.) 1999: The tourist city. London: Yale Univ. Press.

Kabish, Nadja; Haase, Dagmar 2011: Diversifying European Agglomerations: Evidence of Urban Population Trends for the $21^{\text {st }}$ Century. In: Population, Space and Place 17,3: 236-253 [doi: 10.1002/psp.600].

King, Russell; Fielding, Anthony; Black, Richard 1997: The international migration turnaround in southern Europe. In: King, Russell; Black, Richard (Eds.): Southern Europe and the New Immigrations. Brighton: Sussex Academic Press: 1-25.

Massey, Douglas S.; Denton, Nancy. A. 1985: Spatial assimilation as a socioeconomic outcome. In: American Sociological Review 50,1: 94-106 [doi: 10.2307/2095343].

Massey, Douglas. S. 1988: Economic development and international migration in comparative perspective. In: The Population and Development Review 14,3: 383-413 [doi: 10.2307/1972195].

Musterd, Sako 2003: Segregation and integration: A contested relationship. In: Journal of Ethnic and Migration Studies 29,4: 623-641 [doi: 10.1080/1369183032000123422].

Musterd, Sako 2005: Social and ethnic segregation in Europe: Levels, causes, and effects. In: Journal of Urban Affairs 27,3: 331-348 [doi: 10.1111/j.0735-2166.2005.00239.x].

Musterd, Sako et al. 2016: Adaptive behaviour in urban space: Residential mobility in response to social distance. In: Urban Studies 53,2: 227-246 [doi: 10.1177/0042098014562344].

Ne/./o, Oriol et al. 2014: Evolució de la segregació a Catalunya, 2001-2012. Volum I. Presentació i resultats preliminars. Bellaterra: Institut de Govern i Polítiques Públiques (IGOP), Universitat Autònoma de Barcelona.

Newbold, K. Bruce 1996: Internal migration of the foreign-born in Canada. In: International Migration Review 30,3: 728-747 [doi: 10.2307/2547634]. 
Palomares-Linares, Isabel; Feria, José María; Susino, Joaquín 2017: Medida y evolución de la movilidad residencial en las áreas metropolitanas españolas. In: Revista de Sociologia 102,4: 545-574.

Papademetriou, Demetrios G.; Terrazas, Aaron 2009: Immigrants and the Current Economic Crisis. Washington DC: Migration Policy Institute.

Portes, Alejandro; Zhou, Min 1993: The New Second Generation: Segmented Assimilation and Its Variants. In: Annals of the American Academy of Political and Social Sciences 530,1: 74-96 [doi: 10.1177/0002716293530001006].

Pozo-Rivera, Enrique; Rodríguez-Moya, Juana 2018: Impacto de la crisis en los movimientos migratorios en la Comunidad de Madrid (2007-2013). In: BAGE 77: 229-255 [doi: 10.21138/bage.2540].

Prieto, Victoria Rosas; López-Gay, Antonio 2015: Push and pull factors of Latin American Migration to Spain. In: Domingo, Andreu; Sabater, Albert; Verdugo, Richard R. (Eds.): Demographic Analysis of Latin American Immigrants in Spain: From boom to bust. Switzerland: Springer International: 1-28 [doi: 10.1007/978-3-319-12361-5_1].

Pujadas, Isabel; Bayona, Jordi; Gil-Alonso, Fernando 2015: Movilidad residencial y crisis: Tendencias recientes en las regiones metropolitanas españolas. In: Fregolent, Laura; Guerzoni, Marco; Torri, Rosana (Coord.): Porvera casa. Tricase: Youcanprint: 51-74.

Pumares, Pablo 2005: Distribución territorial y movilidad interprovincial de la población marroquí en España. In: Di Comite, Luigi; Rodríguez, Vicente; Girone, Stefania (Eds.): Quaderni 32. Sviluppo demografico e mobilità territoriale delle popolazioni nell'area del Mediterraneo: Italia e Spagna, due paesi a confronto. Bari: Caccuci Editore: 203230.

Quintero-Lesmes, Doris Cristina 2016: Transformaciones territoriales de las migraciones internas de los latinoamericanos en España en tiempos de crisis económica. In: Scripta Nova XX,549-3.

Ratha, Dilip; Mohapatra, Sanket; Silwal, Ani 2009: Migration and Remittance Trends 2009, Migration and Development Brief 11. Washington DC: World Bank.

Ravenstein, Ernst Georg 1885: The laws of migration. In: Journal of the Statistical Society of London 48,2: 167-235 [doi: 10.2307/2979181].

Randolph, Bill; Tice, Andrew 2014: Suburbanizing disadvantage in Australian cities: sociospatial change in an era of neoliberalism. In: Journal of Urban Affairs 36,1: 384-399 [doi: 10.1111/juaf.12108].

Recaño, Joaquín; Cabré, Anna 2003: Migraciones Interregionales y ciclos económicos en España (1988-2001). In: Papeles de Geografía 37: 179-197.

Recaño, Joaquín; De Miguel, Verónica 2012: The Internal Migration of Foreign-Born Population in Southern Europe: Demographic Patterns and Individual Determinants. In: Finney, Nissa; Catney, Gemma (Eds.): Minority Internal Migration in Europe. Surrey: Ashgate Publishing - International Population Studies Series: 239-262.

Rees, Philip et al. 2017: The impact of internal migration on population redistribution: An international comparison. In: Population, Space and Place 23,6: e2036 [doi: 10.1002/ psp.2036].

Rérat, Patrick 2012: The new demographic growth of cities: The case of reurbanisation in Switzerland. In: Urban Studies 49,5: 1107-1125 [doi: 10.1177/0042098011408935].

Rogers, Andrei; Henning, Sabine 1999: The internal migration patterns of the foreignborn and native-born populations in the United States: 1975-80 and 1985-90. In: International Migration Review 33,2: 403-429 [doi: 10.1177/019791839903300205]. 
Sabater, Albert; Bayona, Jordi; Domingo, Andreu 2012: Internal migration and residential patterns across Spain after unprecedented international migration. In: Finney, Nissa; Catney, Gemma (Eds.): Minority Internal Migration in Europe. Surrey: Ashgate Publishing - International Population Studies Series: 293-311.

Sabater, Albert; Galeano, Juan Martín; Domingo, Andreu 2013: La transformación de las comunidades mayoritarias y la evolución de los enclaves étnicos residenciales en España. In: Migraciones 33: 11-44.

Sharkey, Patrick 2012: Residential Mobility and the Reproduction of Unequal Neighborhoods. In: Cityscape 14,3: 9-31.

Smith, Darren P. 2019: Population geography II: The r/age of migration. In: Progress in Human Geography 43,4: 729-738 [doi: 10.1177/0309132518760098].

Thiers-Quintana, Jenniffer; Gil-Alonso, Fernando 2019: Dinámicas residenciales de la inmigración latinoamericana en las metrópolis de Barcelona y Madrid: cambios de tendencias durante la expansión, la crisis y la poscrisis. In: Documents d'Anàlisi Geogràfica [doi: 10.5565/rev/dag.584].

Tyrrell, Naomi; Kraftl, Peter 2015: Lifecourse and Internal Migration. In: Smith, Darren et al. (Eds.): Internal Migration. Geographical Perspectives and Processes. London: Ashgate: 15-30.

Vale, Mario; Malheiros, Jorge 2017: Dinámicas urbanas en el área metropolitana de Lisboa: rehabilitación y segregación socioespacial. Seminario Internacional Las grandes ciudades en transformación. Dinámicas residenciales, segregación y vulnerabilidad. Barcelona.

Viruela, Rafael 2016: La movilidad geográfica de búlgaros y rumanos durante la Gran Recesión en España. In: Documents d'Anàlisi Geogràfica 62,1: 183-206 [doi: 10.5565/ rev/dag.237].

Wolff, Manuel 2018: Understanding the role of centralization processes for cities - Evidence from a spatial perspective of urban Europe 1990-2010. In: Cities 75: 20-29 [doi: 10.1016/j.cities.2017.01.009].

Wolff, Manuel; Wiechmann, Thorsten 2018: Urban growth and decline: Europe's shrinking cities in a comparative perspective 1990-2010. In: European Urban and Regional Studies 25,2: 122-139 [doi: 10.1177/0969776417694680].

Zorlu, Aslan; Latten, Jan 2009: Ethnic Sorting in The Netherlands. In: Urban Studies 46,9: 1899-1923 [doi: 10.1177/0042098009106023].

Prof. Dr. Fernando Gil-Alonso $(\bowtie)$, Jenniffer Thiers-Quintana. Department of Geography, Universitat de Barcelona. Barcelona, Spain.

E-mail: fgil@ub.edu, jkthiers@gmail.com

URL: http://www.ub.edu/grptc/index.php/ca/component/content/article/8membres/27-fernando-gil-alonso.html http://www.ub.edu/grptc/index.php/ca/component/content/article/8-membres/34jenniffer-thiers.html 


\section{Comparative Population Studies}

WWW.comparativepopulationstudies.de

ISSN: 1869-8980 (Print) - 1869-8999 (Internet)

\section{Published by}

Prof. Dr. Norbert F. Schneider

Federal Institute for Population Research D-65180 Wiesbaden / Germany

\section{(c) BY-SA}

2019

\section{Managing Editor \\ Prof. Philip Rees \\ Dr. Katrin Schiefer}

\section{Copy Editor}

Julia Luther

\section{Editorial Assistant}

Beatriz Feiler-Fuchs

Wiebke Hamann

\section{Layout \\ Beatriz Feiler-Fuchs \\ E-mail:cpos@bib.bund.de}

\section{Scientific Advisory Board}

Karsten Hank (Cologne)

Michaela Kreyenfeld (Berlin)

Marc Luy (Vienna)

Natalie Nitsche (Vienna)

Peter Preisendörfer (Mainz)

Zsolt Spéder (Budapest)

Rainer Wehrhahn (Kiel)

\section{Board of Reviewers}

Martin Abraham (Erlangen)

Laura Bernardi (Lausanne)

Hansjörg Bucher (Bonn)

Claudia Diehl (Konstanz)

Andreas Diekmann (Zurich)

Gabriele Doblhammer-Reiter (Rostock)

Jürgen Dorbritz (Wiesbaden)

Anette Eva Fasang (Berlin)

E.-Jürgen Flöthmann (Bielefeld)

Alexia Fürnkranz-Prskawetz (Vienna)

Beat Fux (Salzburg)

Joshua Goldstein (Berkeley)

Sonja Haug (Regensburg)

Hill Kulu (Liverpool)

Aart C. Liefbroer (The Hague)

Kurt Lüscher (Konstanz)

Emma Lundholm (Umeå)

Nadja Milewski (Rostock)

Dimiter Philipov (Vienna)

Roland Rau (Rostock)

Tomáš Sobotka (Vienna)

Jeroen Spijker (Barcelona)

Olivier Thévenon (Paris)

Helga de Valk (Brussels)

Heike Trappe (Rostock)

Michael Wagner (Cologne) 